NBER WORKING PAPER SERIES

\title{
THE ROLE OF COMPANY STOCK IN DEFINED CONTRIBUTION PLANS
}

\author{
Olivia S. Mitchell \\ Stephen P. Utkus \\ Working Paper 9250 \\ http://www.nber.org/papers/w9250 \\ NATIONAL BUREAU OF ECONOMIC RESEARCH \\ 1050 Massachusetts Avenue \\ Cambridge, MA 02138 \\ October 2002
}

The authors are grateful for comments provided by Shlomo Benartzi, Richard Hinz, Doug Kruse, Nick Souleles, Jack VanDerhei, and the Labor Studies group at the NBER; and for research assistance from Kathleen Callan, Walter Lenhard, William Nessmith, and James Troyer of Vanguard. Financial support for this research was provided by the National Bureau of Economic Research and the Pension Research Council. This study is part of the NBER program on the Economics of Aging. The views expressed herein are those of the authors and not necessarily those of the National Bureau of Economic Research.

(C) 2002 by Olivia S. Mitchell and Stephen P. Utkus. All rights reserved. Short sections of text, not to exceed two paragraphs, may be quoted without explicit permission provided that full credit, including (C) notice, is given to the source. 
The Role of Company Stock in Defined Contribution Plans

Olivia S. Mitchell and Stephen P. Utkus

NBER Working Paper No. 9250

October 2002

JEL No. G2, G3

\begin{abstract}
$\underline{\text { ABSTRACT }}$
This paper explores the risks and benefits of holding company stock in employer-sponsored defined contribution (DC) retirement plans. We address three questions: (1) What is the role and function of company stock in such plans? (2) Who might be affected by enhanced portfolio diversification in such plans? and (3) What mechanisms exist, or might be developed, to enhance portfolio diversification if more diversification were deemed useful? Firms offer company stock within DC plans in an effort to enhance economic performance, though evidence is mixed on productivity gains from stock ownership. We demonstrate that concentrated stock positions arise most often in larger firms' DC plans where sponsors direct employer contributions and restrict diversification. Stock concentration also arises because participants systematically underestimate the risk of employer stock and over-rely on its past performance in making investment decisions. In a retirement system with concentrated stock positions, there will always be some participants who forfeit DC plan savings to firm bankruptcy. Encouraging plan diversification mitigates this risk, but it could also induce some companies to redirect plan contributions to other forms of stock compensation or to replace stock contributions with cash compensation. We conclude by describing policy tools that might be used to encourage diversification and discuss conditions for their effective implementation.
\end{abstract}

Olivia S. Mitchell

Professor of Insurance and Risk Management The Wharton School

3641 Locust Walk, Rm. 304 CPC

Philadelphia PA, 19104-6218

and NBER

mitchelo@wharton.upenn.edu
Stephen P. Utkus

Principal

Vanguard Center for Retirement Research

100 Vanguard Boulevard, J24

Malvern, PA 19355

steve_utkus@vanguard.com 


\section{The Role of Company Stock in Defined Contribution Plans}

In the United States, defined contribution (DC) pensions have often relied on employer common stock as an essential component of their investment portfolios, particularly in the case of plans sponsored by large employers. Company stock in retirement plans has also been used to encourage stock ownership among rank-and-file employees, with the intent of enhancing employee productivity and boosting shareholder value. It is against this backdrop that recent stock market shocks have highlighted the dangers to DC plans of heavy reliance on a single company's stock. Prominent firms including Lucent, Enron, and Worldcom, have recently seen their stock prices drop precipitously or collapse entirely, prompting lawsuits from plan participants who lost billions of dollars of retirement saving. These and other company stock losses have kindled Congressional debate regarding the proper role of company stock in DC plans over the extent to which these plans should emphasize investment diversification in pursuit of retirement security, on the one hand, versus potential productivity gains that might be attributed to employee stock ownership, on the other.

This chapter explores several aspects of this debate. First, we offer essential background regarding the role of company stock in U.S. pension plans. After surveying the legal and fiduciary status of company stock, we briefly review the role of Employee Stock Ownership Plans (ESOPs) and combined 401(k)/ESOP (or KSOP) plans. Second, we analyze holding patterns of company stock in DC retirement plans. Next, we evaluate explanations offered for why employers and employees tolerate (or even prefer) high levels of company stock holdings, and then we provide an assessment of the impact of concentrated holdings of company stock on retirement incomes. A final section sketches policy alternatives and concludes. 


\section{Company Stock in US Defined Contribution Pensions}

Employers in the U.S. may elect to offer retirement programs in addition to paying into the national mandatory Social Security system, and they are encouraged to do so by a variety of federal income tax incentives. About half the civilian private-sector labor force today is covered by a company-sponsored retirement plan. Many plan types and plan designs are permissible under current law: some employees receive a promise of future retirement benefits in defined benefit (DB) plans, while others receive a promise of a fully-funded current contributions to DC plans. Total private pension assets stand at about $\$ 4$ trillion, roughly divided between $\mathrm{DB}$ and DC plans.

Two decades of growth have firmly established the central importance of DC plans in the U.S. retirement marketplace. There are now over 700,000 corporate DC pension plans covering nearly 56 million workers and managing over $\$ 2$ trillion in assets; all evidence points to increasing growth in this sector for the foreseeable future. ${ }^{1}$ By comparison, there are only 56,000 DB retirement plans covering about 23 million active participants (see Table 1), and DB plans continue to decline over time in terms of number and coverage.

\section{Table 1 here}

The Pension Legal and Fiduciary Framework. The key legislation governing U.S. private sector retirement plans is the Employee Retirement Income Security Act of 1974 (ERISA). This law requires plan fiduciaries, who usually include the plan sponsor as well as plan administrators and advisers, to manage a retirement plan in the participants' best interest. ERISA further requires that fiduciaries must comply with an "exclusive purpose" rule, indicating that the

\footnotetext{
${ }^{1}$ Aggregate 2001 statistics based on the authors' estimates from US Department of Labor and Federal Reserve Board data appear Table 1. The most recent official data on pension assets and participants are from 1998 taken from Form 5500 data filed with the US Department of Labor.
} 
fiduciary must be exclusively loyal to participants and beneficiaries; a "prudent man" rule, specifying that the plan fiduciary must act with the "care, skill, prudence and diligence" that a prudent person acting in a similar capacity would use; and a "diversification rule," requiring that the fiduciary diversify the plan's investments with regard to type of investment, geographic area, dates of maturity, and industrial sector to reduce the chances of large losses (GAO 1997; Joint Committee 2002).

At the time of ERISA's adoption, the dominant US retirement plan was the DB plan, and one of the principal goals of the new law was to ensure adequate private funding of private sector DB benefits. Motivated by the failure of several high-profile companies and their pensions, including Studebaker Corporation in 1963, ERISA mandated investment diversification requirement s for private DB plans. Moreover, it established the Pension Benefit Guaranty Corporation, a federal agency that guarantees a portion of private defined benefit pensions in the event of corporate bankruptcy. In order to mitigate the moral hazard problem of sponsors investing their pension assets heavily in their own company stock, and leaving the liabilities to the PBGC in the event of bankruptcy, Congress instituted a 10 percent limit on DB plan holdings of employer stock.

It is an interesting historical footnote that at the time of ERISA's passage, Congress chose not to extend that same percent limit to DC retirement plans. ${ }^{2}$ This was mainly because, at that time, DC plans consisted mainly of profit-sharing plans to which employers made variable plan contributions based on company earnings, and Employee Stock Ownership Plans (ESOPs) which by design encouraged employers to make employer stock contributions in an effort to

\footnotetext{
${ }^{2}$ Interestingly, the early legislative proposals for ERISA developed early in the Kennedy administration included a 10 percent cap on company stock for both DB and DC plans devised by the Commission on Money and Credit. Cap plans then resurfaced several times, in a cabinet working group on pensions during the Kennedy commission, in pension reform proposals developed during the Johnson Administration, and in the pension debate leading up to ERISA's drafting.
} 
foster employee ownership. DC plans were thus not widely used as a retirement income vehicles and at many large firms, they were supplemental to DB programs. Many prominent employers viewed DC plans as vehicles for promoting employee stock ownership and so they objected to limitations on company stock holdings. ${ }^{3}$

Some also argue that Congress exempted DC plans from the diversification standard and cap so as not to constrain ESOPs, which were explicitly intended to encourage employee investment in employer stock (Hunter, 1994). Consequently DC plans had to comply with the exclusive purpose and prudence standards of ERISA, but not the diversification fiduciary standard nor the explicit 10 percent limit on company stock holdings. ${ }^{4,5}$

Five years after ERISA passed, Congress authorized the creation of 401(k) plans. Previously, the Internal Revenue Service as tax authority had crafted regulations allowing employees to make tax-deferred contributions into profit-sharing plans. The Revenue Act of 1978 codified these rules into section 401(k) of the Internal Revenue Code, which in effect permitted a type of DC profit-sharing financed by pre-tax employee contributions. As such,

\footnotetext{
${ }^{3}$ One key opponent of a 10 percent cap on employer stock in DC plans was Sears Roebuck from Chicago, which offered a profit-sharing plan invested exclusively in Sears' stock. Because of the stock's strong performance through much of the 1950s and 1960s, it proved difficult to persuade employees to diversify: that profit-sharing plan yielded very generous payouts to its participants, paying retirees sometimes five times their pre -retirement salaries. Unwillingness to limit profit-sharing programs such as Sears' led to the elimination of the 10 percent cap on DC plans proposed in the 1970's; see Gordon (1984).

${ }^{4}$ Technically, "individual account" DC plans, in which accounts are maintained for individual workers, are exempted from ERISA's diversification requirement (Buckley, 2001). Today these plans include the 401(k) plan (a type of profit-sharing plan), and also traditional profit-sharing and ESOP plans. Another type of DC plan is the money purchase pension plan, in which employer contributions are based on a fixed percentage of pay. These latter plans are considered a form of "pension plan;" they are not guaranteed by the PBGC, but they are subject to the same 10 percent cap on stock holdings as are DB plans. Money purchase plans are also required to offer employees an annuity option upon distribution of plan assets. Finally, some pre-ERISA DB and DC plans are exempt from the 10 percent rule.

${ }^{5}$ Regulations issued in 1992 under ERISA section 404(c) provide a modest incentive for employers to end directed contributions into company stock. Under these regulations, sponsors are provided limited fiduciary liability relief for employee investment decision-making, as long as certain conditions are met. The most important requirement is that participants must exercise independent control over plan assets and must have an opportunity to diversify plan assets among a range of investments. Thus, plans where the employer directs contributions into company stock are ineligible for 404(c) protection, whereas discretionary plans where the participant makes all investment choices are (assuming they meet other technical requirements).
} 
401(k) plans were also exempted from the 10 percent cap on company stock holdings. The subsequent explosive growth of 401(k) plans produced an environment in which this plan type is now the dominant form of private sector retirement plan, accounting for over 80 percent of all DC assets and 40 percent of all private sector retirement assets (authors' estimate, year-end '01). In tandem, the use of company stock has now become widespread among many private sector retirement arrangements, even though Congress originally authorized it for ancillary retirement plans like profit-sharing plans and ESOPs.

Even before the recent equity bear market, there were inklings of the exposure arising from concentrated DC stock holdings. In 1997 the retail chain Color Tile filed for bankruptcy, at which point 80 percent of its retirement plan proved to be invested in company assets, and the firm's failure produced substantial losses for plan participants. ${ }^{6}$ Concern over the Color Tile case prompted Congress to reconsider imposing a mandatory 10 percent cap on DC company stock holdings, but many large employers opposed a cap. Congress consequently adopted a narrower restriction, prohibiting employers from compelling workers from invest more 10 percent of their own 401( $k$ ) contributions in company stock unless employees could reallocate those investments at will. This new rule did not prohibit employees from voluntarily holding company stock over the 10 percent cap nor did it apply to ESOPs or profit-sharing plans (England, 1997).

The equity bear market of 2001-02 once again made participants and policymakers aware of the risks associated with undiversified DC plan investments. Several prominent firms with

\footnotetext{
${ }^{6}$ This was not precisely a garden-variety company stock purchase plan. England (1997) reported that the Color Tile 401(k) plan had purchased several stores from the parent firm and then leased them back to the company at belowmarket rates. Subsequently "(s)ome of these stores stopped making their lease payments, cutting cash flow into the plan. Plan administrators froze payouts, telling participants in a May 10 letter that they had no idea when they might resume or what value could be recovered from these investments."
} 
company stock in their 401(k) plans experienced severe drops in stock prices (see Table 2$){ }^{7}$ leading to related litigation directed at plan sponsors and providers. ${ }^{8}$ Since company stock is statutorily exempt from ERISA's diversification requirement in DC plans, this litigation mainly focused on plan sponsors' alleged failure to comply with ERISA's prudence standard.

\section{Insert Table 2}

Worries over exposure to company stock in DC plans has recently spurred several employers to change the structure of their DC plans. Federal Mogul, a manufacturer reeling from asbestos litigation, saw its share price collapse from $\$ 70$ to $\$ 1$ per share, at which point the company ended employer-matches of stock contributions to its retirement plan and eliminated company stock as an investment option altogether (Jacobius, $2001 \mathrm{a}$ and b). Polaroid

Corporation and US Airways, two firms that recently entered bankruptcy, appointed independent trustees to oversee company stock holdings in retirement plans. Other sponsors have begun to liberalize restrictions imposed on diversification of company stock holdings (Chen, 2002 a and b). These and other losses due to company stock in DC plans have also fed into the broader national debate about corporate governance, the role of the accounting profession, and the ways in which stock and stock options are used in executive compensation packages. ${ }^{9}$

\footnotetext{
${ }^{7}$ The debate over company stock has focused on precipitous drops in stock values, but single-stock risk can also be felt more gradually, over longer periods. One such instance is the bankruptcy of Kmart Corporation in January 2002. Kmart reported that 14 percent of its DC plan was invested in company stock at the time of its bankruptcy (Schneyer, 2002), though stock accounted for some 28 percent of plan assets in 1995 (Paton, 2002). Indeed, over the decade ending in 2001, Kmart was one of the poorest performing stocks in the Standard \& Poor's 500 Index, losing 75 percent of its value as compared to a gain of 238 percent for the S\&P 500. In a similar vein, the bankruptcy of Polaroid Corporation in 2001 reflected a long-term deterioration in its core business (Krasner 2002, Deutsch 2001).

${ }^{8}$ Targets of litigation included telecommunications firms Lucent Technologies, Nortel Networks, Global Crossing, Qwest, SBC, and Worldcom; energy companies Enron Corporation, CMS Energy, Duke Energy, Halliburton and Williams Companies; and firms such as Providian Financial Corporation and Rite Aid Corporation (Plan Sponsor, 2002). Litigation against IKON Office Solutions was settled in May 2002 with the firm agreeing to end restrictions on participants' ability to diversify employer stock contributions after two years of service.

${ }^{9}$ Senior executives at several firms allegedly reaped substantial gains from the sale of personal stock holdings prior to losses incurred by non-executive workers. Executives were said to have distorted financial results in order to maximize reported company earnings and stock option gains. Worldcom reported billions of dollars in accounting
} 
Employee Ownership and Employee Stock. Controversy over company stock has focused mainly on the role of $401(\mathrm{k})$ plans, though it must be acknowledged that the issue is far more complex since employers are permitted flexibility in retirement plan design under U.S. pension law. In particular, many of the largest so-called 401(k) plans that hold high levels of company stock are actually not garden-variety $401(\mathrm{k})$ plans. Instead, they are what is known as “combination" plans, mixing 401(k) features with a profit-sharing plan, or 401(k) features with an Employee Stock Ownership Plan in a design known as a KSOP. Hence understanding the role of company stock in DC plans also requires a perspective on ESOPs and KSOPs in the U.S. retirement market.

An ESOP is a defined contribution retirement plan in which the employer makes discretionary contributions of company stock to workers' accounts. ${ }^{10}$ Philosophical support for ESOPs derives from an era when policy interest in workers' ownership of their firm's stock trumped the need to diversify portfolio investments. Louis Kelso, a California businessman, promoted the virtues of employee stock ownership during the 1950s; later, Peter Drucker espoused them as a vehicle for "worker capitalism" (Drucker, 1979). The exact number of ESOPs today is in some dispute: the National Center for Employee Ownership (NCEO) reports that there are 11,500 ESOPS covering almost 9 million employees and holding about $\$ 500$ billion in assets (NCEO, 2002), while Perun (2000) finds fewer ESOPS, on the order of 8,100 such plans, or just over 1 percent of all retirement plans.

errors that masked true earnings; at Enron and els ewhere, sham transactions were ostensibly used to boost short-term earnings and stock prices. The accounting firm Arthur Andersen was convicted of obstruction of justice in the Enron case.

${ }^{10}$ For more on ESOPS see Hallman and Rosenbloom (2000) and Smiley and Brown (2000). 
Tax law specifically authorizes such plans to invest principally, if not exclusively, in the stock of the employer. ${ }^{11}$ ESOPs are thus intended to encourage employee ownership of a firm's stock, and they are also used to accumulate wealth for retirement. As currently structured, most ESOPs typically restrict participants from diversifying company stock though sponsors may adopt more liberal rules. Current law stipulates that ESOPs may require participants to hold company stock until (the later of) age 55 or 10 years of service; past that point, participant s may begin diversifying gradually but need not fully diversify until the participant attains at least age 60. Since the U.S. median retirement age is now 62, ESOPs give workers approaching retirement little chance to recover financially in the event of a collapse in their employer's stock price.

Unlike other DC plans, ESOPs offer a unique privilege making them a tax-preferred vehicle to the plan sponsor, via the ability to leverage plan assets. ${ }^{12}$ In an employee-owned firm, this feature allows an owner to use an ESOP to acquire bank financing for capital investment, and then company earnings are used to pay off the debt over time. In publicly-held firms, leveraged ESOPs are used by managers to undertake leveraged buyouts or to stave off hostile takeovers. $^{13}$ An important rationale is that employees' voting control may be exercised over the

\footnotetext{
${ }^{11}$ The tax law definition that ESOPs must invest "principally" in employer securities would seem to imply that some diversification would be common in ESOPs. The US Department of Labor has suggested as much (in an amicus court brief filed by the DOL Secretary in Moench v. Robertson, a 1995 court case involving an ESOP). Yet most ESOPs are heavily invested in stock of the sponsoring employer.

${ }^{12}$ In a leveraged ESOP, the plan, using either bank debt or a loan from the employer, buys a large block of employer shares, which are held as "unallocated" (not yet designated to individual participants). Each year, as the employer makes tax-qualified contributions to the ESOP, a portion of the bank debt, both principal and interest, is paid off, and a corresponding value of the unallocated shares is transferred to individual employee accounts. Under prior law, the bank making the ESOP loan also received special tax incentives.

${ }^{13}$ For example, in 1988, Polaroid Corporation utilized an ESOP to buy back shares and maintain independence in the face of a hostile bid from Shamrock Holdings (Deutsch, 2001). This contemporary case is illustrative of the risks involved in an undiversified ESOP. Polaroid filed for bankruptcy in 2001, and employees lost substantial savings accumulated in the Polaroid ESOP (Krasner, 2002).
} 
entire block of leveraged shares held by the plan. ${ }^{14}$ Thus employees sympathetic to management can, through a leveraged ESOP, exert voting authority over a block of shares larger than that which they own directly. Leveraged ESOPs also bring other benefits. ${ }^{15}$ While interest payments on an ESOP loan are deductible to the company, like other corporate interest payments, employers may also use dividends paid on the unallocated ESOP shares to defray those interest payments. This in essence allows dividend income to be transferred to participant-shareholders free of corporate income tax. ${ }^{16},{ }^{17}$

Media reports about the concentration of company stock in retirement programs have sometimes confused the difference between ESOPs and 401(k) plans. For instance, some 401(k) plans named as having high concentrations of employer stock are actually ESOP-centered programs. The confusion is understandable: although the purpose of an ESOP is to provide for employee ownership of the company's shares, ESOPs sometimes appear to be retirement plans, especially when they are combined with other types of DC retirement plan features. As one

\footnotetext{
${ }^{14}$ When tallying shareholder votes, unallocated shares are generally voted in the same proportion as the allocated shares held by and voted by employees. However, plan fiduciaries are still required to exercise prudent judgment and may vote contrary to employee decisions.

${ }^{15}$ Leveraged ESOPs also offered certain financial reporting benefits in the past. Under old accounting rules (grandfathered for certain firms), ESOP debt could remain off of the employer's balance sheet. Contributions to the ESOP could be reported at historic cost, not market value, understating the cost of pensions, at least during the term of the ESOP loan. Some existing ESOPs still take advantage of these benefits. As a result, firms report higher earnings on their shareholder financial statements than they otherwise might.

${ }^{16}$ Principal payments on the loan are seen as deductible too, as they are in the form of tax-qualified employer contributions to the plan. Freiman (1990) argues that employers have overstated these tax benefits, as both interest and dividend payments on ESOP loans constitute a form of compensation, which would otherwise be deductible in paid under a different form. Chaplinsky and Niehaus (1991) reaffirm that it is the tax sheltering of dividend payments that offers a meaningful tax benefit. To maximize this benefit, some employers utilize high-yielding preferred stock, rather than low-yielding common shares, in a leveraged ESOP.

${ }^{17}$ Other ESOP benefits accrue to family- or privately-held firms. ESOPs are a tool of succession planning, providing liquidity to a founding family or owners through a private sale to employees. Owners of privately-held firms receive tax benefits when they sell their holdings to an ESOP (Perun, 2000). Privately-held firms also used ESOPs as a source of investment capital; in effect, selling shares to employees through an ESOP offers a private equity capital market for the owners' shares, as well as the opportunity to borrow against that equity. Overall, only 10 percent of ESOPs are sponsored by publicly traded firms, while 90 percent are sponsored by private firms (NCEO, 2002). However, a much higher percentage of ESOP participants and assets are in publicly traded ESOPs because of the public firms' larger size. ESOPs in private firms are supported by a larger percent of employee salary than in publicly traded firms (8-10 percent of pay versus 4-6 percent; NCEO 2002).
} 
example, the Procter and Gamble $(\mathrm{P} \& \mathrm{G})$ retirement program has some 95 percent of its assets invested in company stock. It is not a garden-variety 401(k) plan; rather, it is an ESOP, a profitsharing, and a 401(k) plan, wrapped into one. Within the P\&G plan, both ESOP and profitsharing components are invested in $\mathrm{P} \& \mathrm{G}$ stock. The company does not offer a DB plan; instead, it views the stock-oriented profit-sharing component as a substitute for a DB plan. A 401(k) feature of the plan allows participants to invest their own monies in a range of diversified investment choices for retirement or in P\&G stock (Jacobius, 2001a; Peale, 2002). With ESOP and profit-sharing components invested heavily in stock, and with employees making voluntary 401(k) contributions to $\mathrm{P} \& \mathrm{G}$ stock, the plan is, not surprisingly, highly concentrated.

A partial list of well-known US companies holding high levels of company stock in their corporate plans includes P\&G, Abbott Laboratories, Anheuser-Busch, Ford Motor Company and Pfizer (see Table 3). Each of these firms uses a combination of a 401(k) plan and ESOP feature, known as a KSOP. ${ }^{18}$ Some also use leverage to gain the tax and ownership benefits noted above. Employers' decisions to create hybrid ownership/retirement programs have blurred the distinction between plans designed to enhance employee ownership and plans designed to maximize retirement security. ${ }^{19}$ Recent legislation further confounds the distinction between traditional retirement plans and stock ownership plans, as in the 2001 Economic Growth and Taxpayer Relief Reconciliation Act (EGTRRA) that embodied an attractive new tax incentive for

\footnotetext{
${ }^{18}$ In an ESOP, employers make discretionary contributions of employer stock to workers' accounts. In a KSOP, participants make voluntary $401(\mathrm{k})$ contributions to the $401(\mathrm{k})$ portion of the program. The employer provides a ESOP stock contribution and may also make a matching 401(k) contribution to the 401(k) portion, which may or may not be directed into company stock. The plan may or may not include a profit-sharing contribution, made in cash or stock. The ESOP component may or may not be leveraged.

${ }^{19}$ A number of prominent firms have taken a similar tack, replacing DB benefits backed by diversified portfolios with programs based on company stock. In a so-called "floor offset" plan design, the employer gradually reduces or eliminates benefits under a traditional DB pension plan as it increases company stock contributions to an ESOP. Such programs have further reduced corporate pension expense, but they also have the effect of increasing company stock concentration among workers (Schultz and Francis 2002a). Since 1987, floor-offset arrangements have been generally prohibited if company stock in the DB and ESOP plans exceeds 10 percent of assets. At the same time, the floor-offset programs of a number of prominent employers (including Enron Corporation) were grandfathered under the 1987 law (Kandarian, 2002).
} 
plan sponsors to create ESOPs by making stock dividends reinvested in the ESOP taxdeductible. ${ }^{20}$ Though Congress thought this to be a narrowly written tax benefit for ESOPs, it has proved to be advantageous to many sponsors of traditional 401(k) plans since with a simple plan amendment, the traditional 401(k) plans can be converted to a KSOP, often with a substantial corporate tax deduction (Schulz and Francis, 2002 a and b; Anand, 2001). Estimated tax deductions for certain large employers converting to the KSOP structure are reported in Table 3.

Table 3 here

In all, it is clear that ESOPs and KSOPS are playing a dual role in the company stock debate. For large, publicly-traded firms, leveraged ESOPs may be used for tax and financial reporting benefits, and to enhance employee voting control in corporate control and takeover transactions. In smaller firms, leveraged ESOPs have played an important role in financing employee-owner acquisitions. And for privately held firms, succession and other tax benefits flow to the company's original stockholders, as a result of ESOPs.

\section{Patterns of Concentrated Company Stock Holdings}

Next we describe how and where concentrated stock positions arise in DC retirement plans. $^{21}$ There is no central source of data on company stock exposure, so we review both government statistics and firm surveys to gauge patterns of exposure. Data from the US

\footnotetext{
${ }^{20}$ Under EGTRRA, employers can more readily qualify for a corporate tax deduction for dividends reinvested in an ESOP by participants. Earlier tax law allowed a similar deduction, but typically required payment of the dividend to the employee. In order to qualify for the ESOP deduction, sponsors must recast their 401(k) plan as an ESOP, at least insofar as the employer contribution is concerned. Sponsors must give participants the right to receive dividends in lieu of being reinvested in the plan. There are also technical requirements that must be met, including requirements for separate nondiscrimination testing and participant pass-through voting.

${ }^{21}$ Company stock holdings by employees may result from other programs including stock option offerings, employee stock purchase plans, and a wide range of executive compensation arrangements (Lambert et al. 1991; Hall and Murphy 2001). We do not consider these here, focusing instead on what workers tend to see as retirement systems.
} 
Department of Labor (USDOL) suggests that about 16 percent of DC assets were invested in employer stock in 1998 (see in Table 4). ${ }^{22}$ Rolling the estimates forward, we estimate that DC assets stood at $\$ 2.1$ trillion in 2001 , so company stock holding amounted to $\$ 340$ billion at yearend. $^{23}$ The fraction of plan assets in employer stock also varies across plan type, with stock bonus plans / ESOPs being the most concentrated, and profit-sharing/thrift saving plans (which include 401(k) plans) somewhat less so. By the end of the 1990s, each plan type appeared less concentrated than in 1993; this trend likely resulted from the growth of small 401(k) plans which are less likely to offer company stock.

\section{Table 4 here}

The conclusion that only 16 percent of DC assets overall are concentrated in company stock gives a misleading view since it represents an average over all DC plans in the US, and it includes plans that do not offer company stock as an investment option. To measure exposure to company stock among plans offering company stock, we rely on data from the Participant-

Directed Retirement Plan Data Collection Project sponsored by the Employee Benefits Research Institute (EBRI) and Investment Company Institute (ICI). ${ }^{24}$ According to this survey, company stock represented 19 percent of 401(k) assets, a figure comparable to the USDOL's 16 percent

\footnotetext{
${ }^{22}$ These data are drawn from plans that must file Form 5500 with the USDOL; they exclude life insurance reserves used to fund corporate retirement plans.

${ }^{23}$ This estimate is derived by projecting the 1998 USDOL data from 5500 plans to 2001 (see Table 1). Our figure agrees with other estimates in the literature; see Benartzi (2001). Higher estimates suggest that company stock represents $\$ 500$ billion of DC assets, but this figure uses an erroneous calculation (it applies the 29 percent of company stock in 401(k) plans that offer company stock to all DC assets including plans lacking stock).

${ }^{24}$ The EBRI/ICI dataset includes more than 35,000 plans with a 401(k) feature, 12 million active 401(k) plan participants, and nearly $\$ 580$ billion in $401(\mathrm{k})$ assets; see Holden and VanDerhei (2001a and b) and VanDe rhei (2002).
} 
estimate for all DC plans. ${ }^{25}$ Nevertheless, exposure levels in 2001 are far higher among the plans offering company stock: here, company stock accounted for 29 percent of plan assets.

Another key fact is that company stock is available in only a small fraction of all DC plans: only 3 percent of 401(k) plans actually offer company stock as an investment option (see Table 5). Yet because these plans are mainly sponsored by large firms, they account for a substantial subset of the DC plan participant and asset universe. Consequently, those firms offering company stock include 42 percent of all DC plan participants and 59 percent of all DC plan assets. $^{26}$ To put it differently, only 3 percent of 401(k) plans offer company stock, but some 23 million DC plan participants have access to company stock within their employer plans, and those DC plans command assets of $\$ 1.2$ trillion, in total.

\section{Table 5 here}

Other surveys confirm the conclusion that company stock held in DC plans is a large-firm phenomenon: the Profit-Sharing / 401(k) Council of America reports that 72 percent of plans with 5,000+ participants offer company stock as an investment option, while only 6 percent of firms with fewer than 100 employees do (PSCA, 2001). A different survey by Fidelity (2001) shows that 62 percent of plans with 2,500+ participants offer company stock, while only 2 percent of firms with less than 500 employees do. Asset allocation levels to company stock are also a function of plan size. Company stock represents 43 percent of average assets among plans with 5,000+ employees, but less than 10 percent of assets in small plans (PSCA, 2001).

\footnotetext{
${ }^{25}$ Kruse (2002) indicates that DOL data do not separately account for company stock holdings held within collective trusts. According to his calculations, if these holdings are properly reflect in the overall totals, the percent of DC plan assets in company stock rises from 16 percent to 20 percent, a figure consistent with data from EBRI/ICI.

${ }^{26} \mathrm{The}$ EBRI/ICI data also indicate that, within the 3 percent of plans offering company stock, 29 percent of plan assets are invested in company stock. Applying this measure to our estimates for 401(k) and DC plan assets for 2001 , it suggests a range for company stock holdings of $\$ 290$ billion to $\$ 359$ billion, confirming the results from the USDOL data of $\$ 340$ billion.
} 
Because company stock is more common among plans sponsored by large firms, concentrated positions in company stock also affect a substantial number of plan participants. We estimate the number of DC participants with concentrated positions in company stock within plans offering company stock in Table 6, drawing on EBRI/ICI concentration data for 401(k) plans. Out of approximately 23 million DC participants offered company stock, it appears that just over 12 million participants are less concentrated, holding 20 percent or less of their DC plan balance in company stock. Meanwhile, we estimate that nearly 11 million plan participants have a concentrated stock position exceeding 20 percent. Of these, some 3 million participants hold company stock worth 21-40 percent of their account balances; 2.3 million participants hold 4160 percent; and 5.3 million participants exceed 60 percent of account balances in company stock.

\section{Table 6 here}

Two elements of employer plan design seem to be closely associated with high levels of company stock holdings. One is some employers' requirement to direct employer's own contributions into company stock. Industry surveys show that the requirement to direct employer contributions into company stock is common though not necessarily dominant for plans offering company stock. The Vanguard Group found that 45 percent of plans direct employer contributions to stock, while 55 percent did not. ${ }^{27}$ Moreover, the decision to direct contributions to stock appears to be a function of firm size, with large firms more likely to direct contributions in company stock than small firms. Mercer (2001) finds that 19 percent of all plans surveyed forced a contribution into stock, while 39 percent of larger plans did. When employers direct contributions on a plan's holdings of company stock, the impact appears to be profound (see Table 7). In the EBRI/ICI subsample of 401(k) plans where participants could freely chose to

\footnotetext{
${ }^{27}$ Survey results provided to the authors encompassed 173 sponsoring firms and 264 qualified plans as of June 2001. The sample represented $\$ 65$ billion in DC plan assets covering an estimate 5 percent of the market value of company stock in 2001. Fidelity (2000) and Hewitt (2001) find near-identical results.
} 
invest employer contributions, 22 percent of total assets were held in company stock; by contrast when the employer directed his own contributions into company stock, the average stock exposure was exceptionally high, at 53 percent of average plan assets. Of this total, 20 percent was employer-matching contributions, and 33 percent represented employee voluntary contributions. Since larger firms tend to restrict contribution investment choice, the result is that company stock concentration levels are highest among large firms offering DC plans (Purcell, 2002).

\section{Table 7 here}

Another plan design factor contributing to stock concentration is employer-imposed restrictions on participants' ability to diversify employer investments in company stock. To understand these restrictions we turn to surveys of qualified plan restrictions conducted by Hewitt Associates, William M. Mercer and The Vanguard Group. In analyzing these survey results, we have classified plan restrictions into one of two categories: directed plans, where the company directs all or part of employer contributions to company stock, and discretionary plans, where all contributions are invested at the discretion of the employee. Table 8 reveals that employers who direct their plan contributions be invested in company stock are also those who restrict participant diversification; in effect, these employers mandate employee share ownership. By contrast, employers who leave all investment decisions to employees are also those who permit diversification, or even discourage concentrated company stock holdings through caps or other limits. In effect, this second group appears to take a more voluntary approach to employee share ownership.

\section{Table 8 here}


It is not generally appreciated that restrictions vary widely across directed plans. In some cases, employers specify limits as a function of age, service, or vesting (including statutory ESOP limits); in others, workers must hold stock until termination; and a few set mandatory holding periods. But again reflecting employer heterogeneity, a few directed plans permit immediate diversification, and yet others cap employee stockholding to discourage concentrated positions. $^{28}$ Some plans impose trading limits, either to discourage short-term day trading or to restrict participants' ability to buy or sell during blackout periods. Among discretionary plans, the tendency is for employers to encourage flexibility and diversification: most allow full flexibility, or impose caps and other limits to discourage concentrated holdings. Overall, concentration patterns in company stock have three key characteristics. First, a small fraction of DC plans actually offers company stock, though because these are the largest firms, the y include an estimated 23 million of participants and nearly 60 percent of all DC plan assets. Second, just under half of plans offering company stock direct employer contributions into stock, again more common among larger firms. Third, restrictions on diversification go hand in hand with the decision to direct contributions into stock. Larger employers that direct contributions to stock also typically restrict participants' ability to diversify, in effect, taking a mandatory approach to employee stock ownership. Meanwhile, smaller employers tend to take a more employeevoluntary approach, leaving investment decisions to participants; they are less likely to impose restrictions, or if they do, they set caps on stock holding.

\footnotetext{
${ }^{28}$ There is no evidence that when restrictions are lifted, rank-and-file participants diversify out of company stock, while executives offered stock options do appear to exercise some portion at the point of vesting (Hall and Murphy, 2001).
} 


\section{Rationales for Concentrated Stock Holdings}

Concentration in a single company's stock, as described here, flies in the face of modern portfolio theory and its central tenet of diversification. As a rule, investors should not expect to be rewarded for assuming single-stock risk, since investing in a single stock must be a zero sum game across investors, with participants in the aggregate earning the market return. Retirement plan participants would therefore, according to this view, hold in their portfolios no more than a market-weighted share of their firm's company stock. Further, workers would theoretically be expected to value company stock holdings according to their certainty-equivalent: namely, due to an individual stock's volatility, a 401(k) plan with a match in stock would be valued at less than a 401(k) plan with the same dollar match in cash. Deviations from the diversified "norm" would lead well-informed employers and workers to discount benefit packages that encouraged or mandated the holding of company shares. On the other hand, as the data indicate, it appears as though some employers and participants may either tolerate or actually prefer single-stock exposure. This section considers potential explanations for why employers and plan participants might depart from the theoretically-implied norms.

Employer Motivations. Several explanations might be considered for why some firms encourage and/or mandate employee holdings of company stock, the most widespread of which is that doing so is believed to align stakeholder interests. Employee ownership of company shares, whether within a DC retirement plan or via other stock ownership programs, is argued to boost efficiency, worker productivity, employee morale, and, ultimately, the sponsoring firm's value. Employee-owners are thus thought to be more aligned with the business goals of the firm and as a result should be expected to perform at a higher level. 
This motivational view is pervasive is undoubtedly influential among executives who offer company stock within DC plans, and, as we have shown, given the opportunity, workers do buy employer stock. Yet the open question is whether employee stock holdings have a positive effect on important company outcomes. Evidence on this topic is inconclusive. ${ }^{29}$ Firms that promote stock ownership tend to have employees with more positive attitudes about their firms, but the link to firm performance is not automatic. Companies with ESOPS report 6 percent higher productivity holding other factors constant (Blasi et al. 1996). On the other hand, compulsory stock ownership in DC plans is also more characteristic of large firms, yet the evidence is weakest in favor of employee ownership among such firms. ${ }^{30}$ Productivity gains are smaller in larger firms, perhaps as a result of the fact that workers are less likely to feel they can influence bottom-line results (the "free-rider" problem). In fact, large companies' restrictions on diversifying out of company stock may be an attempt by managers to overcome the inherent productivity problems of large-scale operations. It is also worth noting that recent studies on employee ownership are drawn from a period of exceptional equity market returns; whether more normal equity market results motivate workers is far from clear.

Another issue is whether employee-ownership incentives are influential for workers below the executive ranks. Traditionally stock compensation was restricted to managerial employees, but more recently it has been extended through the rank and file. About half of all

\footnotetext{
${ }^{29}$ Even and McPherson (forthcoming) as well as Ippolito (1998) summarize the positive arguments, noting that employee ownership provides workers with an opportunity to own a stake in the firm that can enhance shareholder value. A number of other studies is reviewed in Kruse and Blasi (1997) and Kruse (2002); a recent extension is found in Oyer and Schaefer (2001).

${ }^{30}$ Related research has also evaluated stock-based executive compensation, since in the US context, a substantial portion of deferred compensation is in the form of company stock or stock options. The evidence shows that chief executives in key industrial companies receive about one-third of their compensation in the form of stock options (Leonard, 1990; Murphy, 2000; Abowd and Kaplan, 1999). Research indicates that company performance is positively associated with executive holding of stocks or stock options, but by much less than one-for-one. In other words, firms compensating key employees using conditional and long-term incentive plans did experience higher equity returns than those lacking such plans, but net shareholder benefits were not necessarily positive.
} 
stock plans offered to US nonmanagerial workers as of 1998 had been either expanded or added after 1996, and there seems to be a trend toward increased stock coverage (Lebow et al., 1999). The growth of DC plans has also produced more concentration in stock among mid- and lower level employee ranks. That said, stock option programs, a major source of equity compensation, are still skewed toward upper-income earners. The Bureau of Labor Statistics (BLS, 2000) reports that 13 percent of employees earning $\$ 75,000$ or more had options grants, while only 1.5 percent of employees earning $\$ 35,000$ to $\$ 49,999$ had such grants.

A different reason that employers might foster employee purchase of company stock is that it could potentially place company stock into friendly hands to maximize managerial interests, say in a takeover defense or to effect leverage buyouts. For 65 of the largest corporate DC plans in the US, we have calculated employee holdings as a percent of outstanding market capitalization. In that sample, DC plan participants controlled some 5.9 percent of the outstanding market capitalization of the average firm. These data represent only DC company stock holdings and exclude other types of stock ownership plans such as employee stock purchase plan and stock options; they also exclude unallocated shares in leveraged ESOPs that the employees may indirectly control. In a tight takeover battle, a 6 percent position held by employees might be very influential (presumably only if employees act in concert). Combined with other employee holdings and stock held by senior management, the total figure of employee-owned stock could be very significant. Nonetheless, overall, the data indicate that DC participants own a small minority holding in the largest firms.

A different, and prominent, argument for employee ownership is that workers may be more productive and amenable to management proposals if they are shareholders. ${ }^{31}$ If true,

\footnotetext{
${ }^{31}$ Under current tax law, company equity offerings are more tax effective from the employee side if provided in the retirement plan instead of in other stock-based (e.g. stock option) plans.
} 
equity-linked compensation would be expected to be widespread in DC plans, and more broadly

as well. Nevertheless, equity-linked compensation is rare among rank-and-file employees, remaining limited to highly-compensated managers. ${ }^{32}$ One reason may be employee risk aversion: to the extent that workers feel that stock exposes them to greater uncertainty than cash compensation, they would demand a risk premium in compensation. Within a retirement plan, well-informed employees would demand more stock to offset the uncertainty and compensate for restrictions imposed on the stock sale. Low or moderate-income workers are also likely to be risk averse, since they have only undiversified human capital, and their largest financial asset is likely the company-sponsored retirement plan. ${ }^{33}$

Some who favor the use of company stock in DC plans argue that contributing stock to their retirement plans costs employers less than when they contribute in other forms, or that equity compensation in effect is "cheaper" than cash compensation (Ward, 2001; Hedges and Neikirk, 2002). By this argument, if employers were prohibited from making contributions in the form of employer stock, the effective cost of employer contributions to retirement plans would be higher. If required to find a substitute for stock, employers would replace current stock contributions with less generous cash contributions. The simplest version this argument is that stock contributions to a DC plan are cheaper when the employer issues new shares. By issuing new shares and contributing them directly to the plan, the firm avoids spending cash on a matching contribution. Issuing new shares preserves cash flow, so this approach might be expected to be popular among cash-strapped firms. The dilemma, of course, is that issuing new

\footnotetext{
${ }^{32}$ Oyer and Schaefer (2002) estimate that the top five executives of firms, accounting for 2 percent of employment, receive 31 percent of the Black-Scholes value of stock options grants; non-executive emp loyees earning more than $\$ 75,000$, accounting for another 4 percent of employment, receive 61 percent of the Black-Scholes value. Meanwhile, employees earning under $\$ 35,000$, accounting for two-thirds of employment, receive just under 2 percent of options value. The National Center for Employee Ownership, cited in Leonhardt (2002), indicates that in 2000, 75 percent of options outstanding were held by the top five executives in options-granting companies.

${ }^{33}$ Social security benefits represent the largest social entitlement program; see Moore and Mitchell (2000).
} 
shares to the retirement plan dilutes existing shareholders' interest; economically, the firm's net present value has been reduced, whether the contribution is in cash or in stock. There is little evidence on the prevalence of issuing new shares for retirement plan contributions. Only half of all firms buy stock in the open market to finance their DC plan contributions, and half issue new stock (Benartzi, 2001); this finding, however, is based on a sample of firms that do or do not make $11 \mathrm{~K}$ filings with the SEC (needed when new shares are issued), so it may simply reflect different interpretations of when an $11 \mathrm{~K}$ filing is needed. Anecdotally, several plan sponsors have suggested to the authors that common practice at large employers is to always expense plan contributions, whether made in cash or stock. ${ }^{34}$ Still others have indicated that the impression that "stock is cheap" may come from older leveraged ESOPs, where plan contributions are reported on financial statements at historic cost, not market value.

It is unclear how common the practice is of issuing new shares. To the extent that some make this argument, it is possible that they are engaged in a kind of "mental bracketing," a narrow framing of the cost issue which overemphasizes the impact of a cash contribution on reported earnings, and downplays the economic cost of shareholder dilution. A cash contribution reduces reported earnings-per-share (EPS) immediately and is highly visible to shareholders. Diluting existing shareholders by issuing new shares has a much smaller, and less visible, effect; and any reduction in the firm's share price from the dilution is likely to be swamped by daily stock price volatility. ${ }^{35}$

\footnotetext{
${ }^{34}$ For this reason, we avoid the nomenclature of employers "making their 401(k) matching contribution in stock"; instead it appears to be common to make a cash contribution and direct that it be invested in stock.

${ }^{35}$ For example, consider a firm with $\$ 1$ billion in earnings, 200 million shares outstanding, and a share price of $\$ 80$. EPS is $\$ 5.00$ per share and the firm's market capitalization is $\$ 16$ billion. A $\$ 50$ million cash contribution to a DC plan will reduced reported EPS by 5 percent to $\$ 4.75$. Yet issuing an additional $\$ 50$ million in shares $(625,000$ shares at the market price) would require an offsetting decline in the stock price from $\$ 80$ to $\$ 79.75$, or about $0.31 \%$, to maintain the firm's current market value. The percentage decline in share price is small in relation to the normal stock market volatility, whereas the reported reduction in earnings is widely publicized to investors.
} 
A different cost argument relates to ESOPs. Here the benefits are more concrete, relating to the unique issuance, tax, and leverage features of ESOPs. Through KSOP programs, public firms may garner higher tax benefits for their 401(k) plans and enjoy other benefits if the ESOP component is leveraged. In terms of issuance, smaller privately-held or family firms may find issuing shares to an ESOP a lower-cost and more flexible method for raising investment capital, without the need to resort to public capital markets. Tax benefits accrue when certain private firms are sold to employee-owned ESOPs, and when dividends are used for interest on a leveraged ESOP loan. In 2001, EGTRRA also boosted tax savings on reinvested ESOP dividends.

Finally, in assessing the cost argument, the issue of cost-effective stock contributions is sometimes confused with two other questions: the question of employer ge nerosity with stock, and the certainty-equivalent value of stock contributions. Under the current DC system, employers contributing stock seek two objectives: encouraging (or mandating) employee stock ownership, and providing a competitive retirement savings benefit. If policy were to restrict employers' ability to offer (or mandate) stock ownership, the argument is that companies might reduce retirement contributions and/or redirect them to other forms of stock ownership. This argument is not necessarily about the inherent cost advantages of company stock; rather, it reflects the employer's desire to encourage stock ownership.

A critical issue in assessing the value of employer stock contributions is how to account for the underlying volatility of the stock. The certainty-equivalent of company stock may be worth much less than the dollars contributed by the employer, depending on the participant's risk aversion and the fraction of other wealth in company stock (Lambert et al., 1991). In other words, a smaller cash contribution with no volatility might be deemed as valuable to plan 
participants as a higher stock contribution with stock-specific volatility. As one example, Meulbroek (2002) estimates that $\$ 100,000$ in company stock is only worth $\$ 42,000$ to an employee with nondiversified holdings. In other words, if restrictions on company stock in employer plans are implemented, and employers decide to replace stock contributions with less generous cash contributions, the change may actually not be welfare-reducing for employees. Employees could be better or equally well off depending on the size of the reduction, the volatility of the stock, participants' risk aversion, and participants' total holdings in company stock.

Two other factors may help explain why employers use company stock in DC plans, particularly larger firms that mandate DC plan stockholding. One is the existence of some other retirement plan such as a defined benefit pension, and the other relates to the volatility of common stock. On the first point, the evidence indicates that large companies are more likely to offer both DB and DC plans; the former are usually traditional DB plans, though some firms have substituted cash balance plans instead. Rosen (2002) reports that three-quarters of all ESOP participants heavily concentrated in company stock also have some other form of retirement plan, although as we note above, many ESOPs are associated not with large firms offering company stock, but instead with small employee-owned firms. Out of the 96 largest corporate DC plans described in a trade publication survey, we find that all but one also offer a DB plan. ${ }^{36}$ A Vanguard in-house survey of employers offering company stock in their DC plans showed that 77 percent of plans with 2,500+ active participants also had a DB plan. Having multiple plans may explain why some employers tolerate high concentrations of company stock:

\footnotetext{
${ }^{36}$ This compilation of the largest 96 corporate DC plans is extracted from a survey of the 200 largest DC plans in the trade publication Pensions \& Investments (2002); we exclude from the initial list public plans and plans sponsored by mutually owned or privately-held firms. Though few in number, these 96 private pension plans account for $\$ 520$ billion in aggregate DC plan assets; the average firm has $\$ 5.4$ billion in DC assets.
} 
in the event of a stock value collapse, workers would still have a retirement benefit from another better-diversified plan. It may also explain why participants might allocate their own contributions to company stock within a DC plan: long-term employees with a guaranteed DB income stream (or with other diversified DC assets) might reasonably seek greater single-stock risk in the DC plan with company stock.

Though this argument makes sense, the data show that having a DB plan cannot explain the pattern of company stock in DC plans. One reason is that traditional DB plans tend to be back-loaded, and hence are not very valuable to workers in the event of layoff or company bankruptcy; rather, it is the long-tenured employees near retirement that may enjoy a significant DB pension. Large firms offering cash balance plans, by contrast, are in the opposite position since they provide a benefit that grows more evenly across the employee's work career. In terms of legal exposure of the employer, offering a DB or other DC plan may be perceived as a possible way of mitigating legal risks arising from lawsuits, though no court precedent exists on the issue.

A different factor that could explain company stock holdings is the risk and return characteristics of company stock itself. Many people would contend that "blue chip" stocks are less risky than stocks of smaller firms: as evidence, we note that the top 20 (and the top 100) stocks in the S\&P 500 are between two and two-and-a-half times as volatile as a broad market index such as the S\&P 500, while small stocks are four times as risky or more. It may be that managers of larger firms with "blue chip' stocks are more willing to assume the fiduciary risks of concentrated holdings, given the generally lower volatility of their shares as a group, whereas managers of smaller firms with riskier stocks are not. 
Employee Motivations. Next we turn to the question of why employees might hold company stock in their retirement plans. One rationale relies on the fact that earnings profiles for many young employees are relatively independent of stock market returns, so some equity investment may be recommended. Recent research uses individual-level income information to explore how employee compensation covaries with aggregate equity returns, long-term bond returns, and returns on other assets (Davis and Willen, 2000; Baxter, 2001). The findings indicate that aggregate equity returns are uncorrelated with occupational income changes, implying that younger savers would do well to hold diversified equities in their portfolios. The research also indicates that in several occupations, income shocks are correlated with portfolios concentrated in large companies and specific industries. These patterns indicate that holding a diversified equity portfolio can make good financial sense, and that younger workers should diversify out of a large firm stock.

In practice, this theoretically appealing advice may be confounded with several factors. One is that workers might be persuaded by the appeal of employee ownership: that is, they might want to own part of their own firms. A second argument is that the tax code makes holding company stock through DC plans appealing since the purchase of company stock is with pre-tax funds, and participants do not pay retail brokerage commissions. While these same tax and price incentives exist for all diversified investment options within the plan, the one exception is the special long-term capital gain treatment of company stock upon distribution. ${ }^{37}$ A third rationale for participants' holdings is the information argument. Employees may feel they have a superior understanding of the firm and its business prospects. This "insider" perspective might induce participants to overweight company stock holdings in the hopes of realizing excess returns on the

\footnotetext{
${ }^{37}$ Given the obscurity of this tax provision, it is debatable how large a factor in plays in participants' initial investment decisions.
} 
stock when the firm's results are reported to public shareholders. If this hope is realized, this informational advantage could lead to a conflict of interest between employee and public shareholders; also, as noted below, few informational advantages might actually exist.

As employees near retirement, many should perceive that company stock investment is unduly risky, since it substantially boosts the variance of eventual retirement incomes. This would apply even for employees of larger companies whose stock price volatility can be at least twice that of a market portfolio. Older workers near retirement may also focus less on future price appreciation and more on downside risk (i.e. the chance of losing money). Offsetting this expectation is the role of other income and wealth holdings. Some 60 percent of DC participants say they are saving outside their employer's plan according to a recent poll (Vanguard, 2001), and many also have housing equity. Further, participants often have spouses or partners with 401(k) and other retirement benefits, and they may feel comfortable taking a concentrated bet on their company's stock if they have these other assets. Finally, if returns to human capital and company stock are believed to be uncorrelated, people may feel more comfortable investing in stock.

Behavioral explanations can be added to conventional reasons for why employees hold company stock. One is employee myopia regarding the risks of company stock: a recent survey of national DC plan participants showed that participants systematically err in assessing the risks of their company stock (Figure 1), rating employer stock as less risky than a diversified equity mutual fund. ${ }^{38}$ Moreover, that survey showed that participants properly rated "individual stocks" as more risky than an equity mutual fund, but they considered their employer's stock as less risky (in effect they perceived their own company stock as less risky other individual stocks).

\footnotetext{
${ }^{38}$ John Hancock Financial Services (2001) reports similar results.
} 
Despite the fact that average volatility of an individual stock is at least twice the volatility of a diversified market portfolio, participants rated individual stocks as only slightly more risky.

\section{Figure 1 here}

Another factor influencing participant allocations to company stock is past investment performance. Participants' decisions to invest their own monies in company stock appear to be related to the stock's long-term total return performance, particularly over 10-year periods (Benartzi, 2001). ${ }^{39}$ When a stock ranks in the top performance quintile, participants devote about 40 percent of their own assets to company stock; if the stock ranks in the bottom performance quintile, participant holdings of stock fall to 10 percent of portfolios. Participants' decisions to over- or under-weight company stock do not seem to depend on "inside information" regarding their firm's prospects: they tend to overweight stocks that later deteriorate and underweight stocks that improve.

Company stock investment decisions by DC plan participants are unusual in another important respect: participants' portfolio mixes are influenced not only by their own preferences and behavior, but also by their employer's plan design decisions. Thus Benartzi and Thaler (2001) find that participants held more equity when the investment menu includes more equity funds; and conversely, participants held less equity when the menu included more fixed income funds. Employers play an important role in the case of company stock, because they select the menu of available investment options, including whether or not to offer company stock in the first place. In addition, as we have seen, some employers direct their contributions to stock and furthermore restrict its diversification; in so doing, they tend to be seen as implicitly endorsing company stock as an investment and encouraging employees to invest their own funds as well. This has been termed the "endorsement effect" in the literature (Benartzi, 2001).

\footnotetext{
${ }^{39}$ Purcell (2002) also reports that stock performance contributes to plan-level concentration in company stock.
} 
Table 7 offers some evidence of an endorsement effect. If participants make all retirement plan investment decisions, holdings of company stock amount to 22 percent of plan assets; by contrast when an employer directs employer contributions to company stock, total holdings of company stock soar to 53 percent of assets. Of that 53 percent, 33 percent is the participant's money and 20 percent is the employer's. Arguably there are differences in directed versus discretionary plans that account for some of the difference. Employers who direct contributions to stock are more likely to be large, well-known companies; their "blue chip" stock may be somewhat less volatile; and they may be somewhat more likely to offer a DB or other

DC plan. Still, the difference in asset allocation patterns between these two groups is striking and suggestive of an endorsement effect. Further, a persuasive case can be made that participants follow the "path of least resistance" in making contribution and investment choices within retirement plans. One such path may be to accept an employer's decision to invest the employer contribution in company stock, and to mimic to some extent that decision in one's own portfolio (Choi, et al. 2001).

\section{Company Stock and Retirement Income Security}

Two distinct goals drive current policy toward tax-qualified retirement saving in the U.S., namely, employee ownership and retirement saving. The policy goal of employee ownership has been encouraged in several different ways. For instance, ERISA exempts company stock from its diversification standard; employers may contribute in company stock and restrict its diversification; no cap is required for company stock in DC plans comparable to that on DB plans; and participants are afforded special tax treatment for company stock on distribution. ESOPs, whether standalone or integrated with a 401(k) feature, also have an array of tax, 
leverage, and other advantages; the passage of EGTRRA as noted earlier enhances the tax benefits further. Currently, tax subsidies amounting to $\$ 55$ billion (in 2002) ${ }^{40}$ and exceptions in fiduciary law permit employers to encourage or mandate employee holdings of company stock in DC plans.

Some firms have therefore emphasized employee ownership aspects of their tax-qualified retirement programs, a finding enunciated in a 1983 opinion of the U.S. Court of Appeals for the Fifth Circuit. Although it referred narrowly to ESOPs, it did summarize the broader arguments regarding company stock in retirement savings plans:

"Congressional policies [...] seem destined to collide. ... On the one hand, Congress has repeatedly expressed its intent to encourage the formation of ESOPs... Competing with Congress' expressed policy to foster the formation of ESOPs is the policy expressed in equally forceful terms in ERISA: that of safeguarding the interests of participants in employee benefit plans by vigorously enforcing standards of fiduciary liability.",41

By contrast, ERISA's prudence and diversification standards derive from a view of the world consistent with modern portfolio theory, which holds that workers should not own stock in a single factory. Instead, they should be encouraged to own a representative fraction of all factories by investing through a fully diversified market portfolio. Departure from a market weighting of any one company's stock will results in labor and capital earnings becoming positively correlated, so firm bankruptcy puts but wages and financial assets at risk.

In order to assess the impact of holding company stock on retirement security, we model retirement incomes for participants holding company stock, taking a system-wide view. The analysis considers three hypothetical portfolios: one invested 100 percent in company stock, a second invested 100 percent in a market portfolio, and a third invested in a 50/50 mix of the two. The hypothetical participant in this exercise receives $\$ 50,000$ in labor earnings and has a total of

\footnotetext{
${ }^{40}$ OMB (2002) notes that this refers to both the tax expenditure due to the exclusion of employer contributions and earnings in 401(k) and ESOP plans.

${ }^{41}$ Donovan v. Cunningham, 716 F.2d 1455, 1466 ( $5^{\text {th }}$ Cir. 1983).
} 
10 percent of earnings contributed to his DC plan; his pension contributions are assumed to grow non-stochastically at 3 percent (to account for inflation). Returns on company stock and the market portfolio are assumed normally distributed with identical expected mean returns of 10 percent. Consistent with the individual stock risk presented earlier, the volatility of company stock is set at 40 percent, twice that of the market volatility of 20 percent. Terminal wealth is log-normally distributed.

The range of results for retiree wealth 30 years hence is generated by a Monte Carlo simulation; results are given in Figure 2. One finding is that median expected wealth declines due to the compounding of more volatile returns, as the percentage of company stock increases in the participant's portfolio. Median wealth with the market portfolio amounts to $\$ 830,000$, but is about half that, $\$ 411,000$, with the company stock portfolio. Extremes of wealth are greater in the best-case company stock scenario, where there is a 5 percent chance of making $\$ 4.1$ million, versus only $\$ 2.7$ million with a market portfolio. Yet in the worst-case scenario, the ordering of outcomes is reversed: the market portfolio provides a low of $\$ 281,000$ while the company stock investor ends up with only $\$ 66,000$ in retirement.

\section{Figure 2 here}

In the aggregate then, more volatile company stock is expected to produce greater wealth extremes in DC plans: there are a few retirement outcomes where DC participants are either exceptional winners or losers. The problem is that policymakers tend to be concerned with downside risk where people forfeit substantial DC assets to firm bankruptcy (e.g. "Enron losers"), rather than the upside risk (e.g. the "Microsoft winners"). Also, median wealth for DC participants with company stock may be lower, ${ }^{42}$ a perhaps counterintuitive finding that results

\footnotetext{
${ }^{42}$ If inducing employees to hold stock actually increased productivity, overall returns might rise. However, as we noted earlier, there is little hard proof of this point.
} 
directly from greater volatility of company stock compounding at a lower rate. In other words, greater diversification would boost employees' median wealth but simultaneously reduce extreme outcomes at both ends of the spectrum. Therefore, curtailing bankruptcy risk for company stock losers also limits the chance of outsized gains for company stock winners. ${ }^{43}$ As a consequence, policymakers face the quandary of whether to permit DC pensions to produce such widely disparate outcomes. Downside, as well as upside, risk from company stock is particularly concentrated for long-tenure employees working for a single firm whose DC assets are bound up tightly with the company. When the stock value drops precipitously, such longtenure workers will experience a substantial loss of lifetime savings. Diversification would logically limit such extreme worst-case as well as best-case outcomes, while less obviously, it will also increase median wealth among all DC plan participants holding company stock.

The dilemma for policyholders is that making DC plans more diversified will not produce readily observable benefits for employers and participants. Thus in the long term, median retirement wealth will likely grow, but it will be difficult to compare results with a companystock-heavy system. Some participants would bankruptcy losses though these will be relatively few; meanwhile, diversification restrictions will be highly visible, particularly at very successful firms.

\section{Policy Choices and Outcomes}

\footnotetext{
${ }^{43}$ A few caveats are in order. Employees often change jobs during their careers, so job changes will keep some participants from accumulating too much in a single stock. Our analysis reflects the worst-case results for a longtenure employee. If participants accumulate several single-stock positions during a career, the retirement outcome will depend on the correlation of returns among the old and the new stocks. Finally, this analysis models outcomes only from the DC component of retirement incomes. Sponsors who also provide a corresponding DB (or other noncompany stock DC) plan will mitigate the risk to total retirement income for covered employees, assuming there is a meaningful vested and accrued DB payout (and taxable savings).
} 
Several policy options have been suggested to encourage DC plan diversification. This section evaluates their potential impact on employer and employee behavior.

Maintain the status quo. One option might be to continue to permit employers substantial flexibility to offer company stock in DC plans of various kinds. The analysis above shows that some participants would forfeit all or most of their DC plan savings to firm bankruptcy, though there will be wealth extremes with some participants receiving very large wealth while others will receive very low benefits with company stock. Median wealth will be lower among DC participants investing in company stock.

Enhance participant risk disclosure. DC plan participants seem to systematically underestimate the risks inherent in company stock, based on evidence provided above. Plan designers seeking to encourage diversification might require periodic disclosure statements encouraging participants to limit their own company stock holdings to some stated limit such as 10 or 20 percent of assets. In view of participants' poor understanding of the risks, repeated risk disclosure might be useful. A difficulty with disclosure, whether passive or active, is that plan sponsors may perceive a conflict regarding their dual roles as company executives seeking to promote employee ownership, and plan fiduciaries seeking to ensure diversification. Perhaps "safe-harbor" disclosure statements could be provided by regulators.

Promote participant investment advice. To encourage further diversification, disclosure might be combined with expanded use of third-party advice providers. Today advice is rarely offered with DC retirement plans, and various proposals have been made to simplify the fiduciary rules surrounding the provision of advice, the subject of a separate policy debate. Yet providing plan participants with investment advice will encourage diversification only if those with highly concentrated positions are actively encouraged to sell those holdings, even when such sales 
might be against the employer's wishes. It is worth noting that the leading providers of advice rely on participants to determine how much company stock they want; they do not explicitly instruct participants to sell company stock as many independent financial planners might (Halsey, 2002).

Strengthen fiduciary oversight. Implicit in the national policy debate as well as employers offering DC plans is the inherent conflict of interest that arises between promoting stock ownership and encouraging diversification. One approach to addressing this conflict would be to propose tougher conflict-of-interest standards, to focus fiduciaries on the risks associated with DC plan investments (Olsen, 2002). A different tack would require that an independent fiduciary be responsible for monitoring company stock performance and recommending steps that employers could take to minimize concentrated stockholdings.

Restrict DC participants from holding “too much” company stock. To discourage participants from holding "too much" company stock, some have recommended minimizing employer restrictions on participants' ability to diversify employer contributions. A different approach would set a statutory cap on company stock holdings in DC plans such as the 10 percent maximum for DB plans. A third proposal, recommended by Olsen (2002), would provide employers with a choice of company stock regimes. If the employer elected to direct contributions into stock to encourage employee ownership, these employees could be prohibited from investing their own contributions in stock. This would prevent the "doubling down" of investments in company stock, when employees concentrate their purchases of stock on top of company contributions. Alternatively, an employer could offer stock as simply another investment option in the plan, but would not direct contributions to stock. Rather, it would be up to the participant to decide whether or not to allocate employer and/or employee monies to the 
option. A different set of choices pertains not to participant or plan design behavior, but instead focuses on tax subsidies. One option would phase out EGTRRA dividend reinvestment incentives for ESOPs and long-term capital gain treatment for distributions of stocks to participants. To raise the relative costs of making contributions in stock, the tax deduction for stock contributions to retirement plans could be reduced.

In assessing these and other options to restrict company stock holdings, we note that there are two competing views regarding the degree of regulation that public policy should impose. Those policymakers that focus on the flexibility of the retirement system, employer support for employee ownership aspects of DC plans, and the central role of individual investment decisions, are likely to emphasize voluntary diversification by participants. By contrast, policymakers concerned about the company executives acting as independent fiduciaries for their stock, participant myopia about risks and performance, and participant inertia generally, are likely to consider statutory rules that mandate diversification. Additionally, any policy change would have to take into account the varied role of ESOPs as standalone plans or hybrid KSOPs, as leveraged or unleveraged plans, and as plans sponsored by public versus private, family, or employeeowned firms.

Develop new pension investment protections. To protect against excessive company stock in DC plans, employers could also offer plan participants insurance against severe loss of company stock value. As with Enron, Worldcom, Kmart, and Polaroid, the dilemma is that if the firm selfinsures, there will likely be no assets available in the worst-case scenario of bankruptcy, and if the firm obtains third party insurance, that coverage could be contested. There is also the morat hazard problem, of firms with insurance "betting the farm" on company stock. Another alternative might be to require DC plans to offer one or two guaranteed investment options such 
as those discussed in this volume (Lachance and Mitchell, this volume). Indeed more than one legislator has already proposed that DC plans offer insured investment products, perhaps on a federal level (Joint Committee, 2002). More research on the feasibility, structure and cost of guarantees is clearly required. ${ }^{44}$

Proposals that would alter the role of company stock in private DC plans might also change employer and employee behavior. The key question is how employers and employees might respond to plans to require diversification. To the extent that actual company stock holdings reflect inertia and risk myopia by both employers and employees, relatively little might change. On the other hand, sponsors or participants with most of their assets in company stock might assign a higher utility to equity-linked compensation than those with, say, 15 percent in company stock. Some of this is employer-based, though as noted earlier, 55 percent of plans offering stock do not direct contributions to stock and are liberal in allowing participant diversification. Even among the 45 percent of company stock plans that direct employer contributions to stock, some have no restrictions on diversification nor do they impose caps.

Some worry that new plan formation could decline, or sponsors might terminate retirement plans, in response to changes in company stock rules. In our view, this seems unlikely. Plan formation is principally a concern among smaller firms where company stock is generally not offered; workers' preferences for wages and firm profitability are reported to be the main obstacles to offering retirement benefits (EBRI, 2001). In terms of plan termination, virtually all large U.S. corporate employers offer DC plans, and though most offer company stock, there is still heterogeneity in the level of stock concentration and the types of restrictions imposed. The universality of DC benefits among large firms would suggest that employers

\footnotetext{
${ }^{44} \mathrm{See}$ http://prc.wharton.upenn.edu/prc/2002confb.html for a range of studies on this topic.
} 
would continue to maintain some DC retirement program in order to remain competitive in the labor market.

Alternatively, some employers may reduce retirement plan contributions when faced with caps or limits on stock. Stock contributions could be replaced with smaller cash contributions or simply smaller stock contributions than before, as the DC plan environment becomes less favorable toward holding company stock. In times of labor scarcity, employers cutting stock contributions would be reducing pay so employer would be expected to have to boost other forms of compensation over time to remain competitive. The substitution may be less than onefor-one on an after-tax basis in the hands of employees, since the employer is no longer directing compensation to a tax-qualified plan. ${ }^{45}$

Yet a different employer response might be to redirect existing retirement plan contributions into other forms of stock compensation. Several choices come to mind as alternative vehicles: for instance sponsors might use stock options, though this might increase accounting scrutiny about options' dilutive effect and the substitution of visible compensation expense for less-transparent option grants. A different possibility would be employee stock purchase plans, which are typically voluntary and lack the compulsory nature of directed employer contributions in DC plans. A third avenue would provide employees with direct grants of stock from the company. These might come in the form of a special restricted class of shares, if feasible. However, compared with options, grants are expensed on income statements under current financial reporting standards; as a result, they are less advantageous in management's eyes compared with options. Since none of these options has the tax benefits, market appeal, and

\footnotetext{
${ }^{45}$ How much less the cash-equivalent value of company stock in pensions plans might be worth is unclear. The fact that it can be substantially less than dollar for dollar is demonstrated by Hall and Murphy (2000), Lambert et al. (1991), and Meulbroek (2000 a and b), among others, in the case of executives, but similar metrics have not been derived for rank and file employees.
} 
transparency (in terms of public and media scrutiny) as do DC plan contributions, it is unlikely that there would be a direct and complete substitution effect, with employers reducing current retirement plan contributions by $\$ 1$ and redirecting the same $\$ 1$ to one of these other forms of compensation. Ultimately, substitution will hinge on employees' value associated with mandatory stock contributions in DC plans as well as employer valuation of these contributions. Assuming that employers who preferred large holdings of company stock by employees will direct some of their contributions to other forms of equity compensation, what might be the impact on retirement plans? One possibility is that employee DC plan participation rates might fall. Evidence indicates that plan participation rates rise with employer matching contributions, though there is some question as to whether it is the size, or the mere existence, of the match that counts most. Large firms, which more often offer company stock, already have lower participation rates, perhaps because they are also more likely to offer another retirement plan. Also as noted above, movement toward diversification and less company stock could raise median wealth, while reducing the chances of exceptional wealth and loss of all assets due to company bankruptcy. On the other hand, depending on workers' preferences and other wealth, risk-averse workers may accept a decrease in total compensation as a result.

The dynamics of employer contributions are further complicated by nondiscrimination testing in DC plans. Nondiscrimination rules require that non-highly compensated employees contribute at some minimum rate; the goal is to ensure that the tax benefits associated with a DC plan are not simply provided to highly-compensated employees. If non-highly paid employees fail to contribute, highly-paid employees will also be limited in their ability to contribute. Employers who decide to reduce plan contributions made in stock (and thereby decrease participation or savings rates among non-highly compensated workers) could inadvertently lead 
to savings restrictions on highly-compensated employees, decreasing the value of the retirement plan benefit for this segment of the employee population.

Finally, what impact might a policy change have on employees? Today an estimated 11 million participants have concentrated stock positions exceeding 20 percent of account assets. If forced to diversify, some of these people will believe themselves worse off since they were required to modify their desired stockholdings. On the other hand, since some participants underestimate the risks of owning company stock, and employer plan design and past performance have a strong influence on their decision to invest, this group might experience lower current satisfaction but greater later benefit in retirement. Yet others will perceive no reduction in welfare, possibly because they are concentrated in stock on an involuntary basis, through a misunderstanding of the risks, or inertia. Given the tendency of participants to overweight stock holdings based on past performance, employees perceiving the greatest welfare reduction will be those employed by firms with a history of strong stock performance.

\section{Conclusions}

This chapter has focused on the role of company stock in employer-sponsored retirement plans, with special attention to how U.S. employers have used company stock within DC plans in an effort to promote employee share ownership, particularly among rank-and-file workers. The stated aim of such ownership is to improve morale, worker productivity, and shareholder value. The data show that only 3 percent of DC plans actually offer company stock as an investment in the US, but since these plans are sponsored by large firms, around half of all private sector DC plan participants, 23 million workers, have access to company stock in their DC plans. Of these, some 11 million participants hold concentrated stock positions exceeding 20 percent of account 
balances; and five million hold positions exceeding 60 percent of account balances. It is surprising that concentrated DC company stock holdings appear to be driven by employer belief that restricting diversification will enhance productivity, in view of the lack of strong evidence on this point. A different explanation is systemic participant decision-making error, where participants erroneously view employer stock as less risky than a diversified equity fund or other individual stocks. There also appears to be evidence favoring the "endorsement effect," in which participants take employer decisions to direct and restrict company stock investments as an implicit recommendation.

Retirement systems with concentrated stock positions will always have some participants forfeit DC plan savings to firm bankruptcy. Company stock in retirement portfolios also leads to greater extremes in accumulated wealth because of its higher volatility, and a lower median wealth, as compared to a system of diversified investments. Policy options for encouraging additional diversification include additional risk disclosure, liberalization of restrictions, maximum caps or limits on company stock, and other strategies. We find that rule changes will have little immediate impact on plan formation or termination, but they may influence employers to redirect some portion of retirement plan contributions to other forms of equity-linked compensation, such as options, stock purchase plans, or stock grants. Whether reductions in stock contributions are welfare-reducing depends on the certainty equivalent value of such stock contributions, not simply on a change in the dollar value of the contribution.

In the end, policymakers face a dilemma. Most proposed reforms, restrictions, and advice, discourage the purchase of top-performing stocks. These will also be highly visible, especially after the fact, while long-term improvements in retirement wealth due to diversification will be difficult to measure and potentially diffuse. Reductions in bankruptcy risk 
will affect only a relatively small group of participants, and the utility gain to risk-averse participants whose plans become diversified may be even harder for politicians to identify. 


\section{References}

Abowd, John M. and David S. Kaplan. 1999. "Executive Compensation: Six Questions that Need Answering." Journal of Economic Perspectives 13: 145-168.

Anand, Vineeta. 2001. "Employers Get a Gift: Treasury Department OKs Break for ESOPs.” Pensions \& Investments, December 24, 2001, p 3.

Baxter, Marianne. 2001. "Social Security as a Financial Asset: Gender-Specific Risks and Returns.” NBER WP 8329.

Benartzi, Shlomo. 2001. "Excessive Extrapolation and the Allocation of 401(k) Accounts to Company Stock". Journal of Finance. LVI (5). October: 1747-1764.

Benartzi, Shlomo and Richard Thaler. 2001. "Naïve Diversification Strategies in Retirement Savings Plans," American Economic Review. 91(1), pp. 79-98.

Blasi, Joseph, Michael Conte, and Douglas Kruse. 1996. "Employee Stock Ownership and Corporate Performance among Public Companies." Industrial and Labor Relations Review 50, 1 (October): 60-79.

Buckley, Allen. 2001. "Eligible Individual Account Plans and ERISA's Fiduciary Duties.” Journal of Pension Benefits. 9 (1). Autumn.

Bureau of Labor Statistics (BLS). 2000. "Pilot Survey on the Incidence of Stock Options in Private Industry in 1999." www.bls.gov.

Chaplinsky, Susan and Greg Niehaus. "Tax Advantages of ESOP Financing.” Benefits Quarterly. Third Quarter, 1991, pp. 26-30.

Chen, Kathy. 2002 (a). "Enron Official Failed to Warn Participants of 401(k) Plan." The Wall Street Journal, February 6, 2002, p. C1.

Chen, Kathy. 2002 (b). "Pension Plans Are Adjusted After Enron." The Wall Street Journal, January 29, 2002, p. A2.

Choi, James J., David Laibson, Brigitte C. Madrian and Andrew Metrick. 2001. "Defined Contribution Pensions: Plan Rules, Participant Decisions, and the Path of Least Resistance.” NBER WP 8655. December.

Davis, Steven J. and Paul Willen. 2000. "Occupation Level Income Shocks and Asset Returns: Their Covariance and Implications for Portfolio Choice.” NBER WP 7905.

Deutsch, Claudia H. 2001. "Market Place: For Polaroid, the Bad News Seems to be the Only News." New York Times. October 4, 2001. www.nytimes.com.

Drucker, Peter. 1976. The Unseen Revolution : How Pension Fund Socialism Came to America. New York : Harper \& Row.

Employee Benefits Research Institute (EBRI). 2001. “The EBRI 2001 Small Employer Summary of Findings." www.ebri.org.sers

England, Robert Stowe. 1997. "Protecting the Participant: Washington Lawmakers Ponder Tighter Regulations for 401(k) Plans." Plan Sponsor. February. www.assetpub.com/archive/ps/9702psfeb/feb97PS44.html

Even, Willia m E. and David A. Macpherson. Forthcoming. "Benefits and Productivity". Benefits for the New Workplace. Eds. Olivia Mitchell, David Blitzstein, Michael Gordon, and Judy Mazo. Philadelphia: University of Pennsylvania Press. 
Farrell, Chris. 2002. "The Problem with Pension Plans”. Business Week Online. Sound Money 1/11/02. New York: McGraw Hill. www.businessweek.com/bwdaily/dnflash/jan2002/nf20020111_3044.htm

Fidelity Investments. 2001. Building Futures: A Report on Corporate Defined Contribution Plans. Boston: Fidelity Investments, 2001.

Freiman, Howard A. 1990. "Understanding the Economics of Leveraged ESOPs." Financial Analysts Journal. March-April, p51-55.

General Accounting Office (GAO). 1997. 401(k) Pension Plans: Extent of Plans' Investments in Employer Securities and Real Property. Washington, DC: November.

Gordon, Michael S. 1984. “The Employee Retirement Income Security Act of 1974: The First Decade: An Information Paper: Why Was ERISA Enacted?" Special Committee on Aging, US Senate. Washington: US GPO: August.

Hall, Brian and Kevin Murphy. 2000. "Optimal Exercise Prices for Executive Stock Options. AER. May.

Hall, Brian and Kevin Murphy. 2001. "Stock Options for Undiversified Executives.” Working Paper. Harvard Business School.

Hallman, G. Victor III and Jerry S. Rosenbloom. 2000. "Employee Stock Compensation Plans.” Handbook of Employee Benefits. Ed. J. Rosenbloom. New York: McGraw Hill.

Halsey, Nicole. 2002. “Advice Providers Differ on Company Stock Treatment." Plansponsor.com. February 11. http://www.plansponsor.com/content/News/Finance/enronadviceprov

Hedges and Neikirk. 2002. "Enron Failure May Not Be Enough to Bring around Lasting Financial Reforms." Chicago Tribune. February 11, 2002.

Hewitt. 2001. Survey Findings: Trends and Experience in 401(k) Plans 2001. Hewitt Associates.

Holden, Sarah and Jack VanDerhei. 2001 [a]. "Contribution Behavior of 401(k) Plan Participants." ICI Perspective. 7(4). Washington, DC. October.

Holden, Sarah and Jack VanDerhei. 2001 [b]. "401(k) Plan Asset Allocation, Account Balances, and Loan Activity in 2000.” ICI Perspective. 7 (5). Washington, DC: November.

Hunter, Barry D. 1994. "ERISA's Authorization of Unlimited Fiduciary Self-Dealing: Employer Stock Acquisition by Defined Contribution Plan Trustees", Journal of Pension Planning and Compliance, Fall.

Ippolito, Richard A. 1998. Pension Plans and Employee Performance: Evidence, Analysis, and Policy. Chicago: University of Chicago Press.

Jacobius, Arleen. 2001 (a). "P\&G Debuts New, Improved DC Plan.” Pensions \& Investments. July 9: 1.

Jacobius, Arleen. 2001 (b). "Company Stops Contributing its Stock to 401(k)." Pensions \& Investments. September 3: 1 .

John Hancock Financial Services (2001). Insight into Participant Investment Knowledge and Behavior, Seventh Defined Contribution Plan Survey.

Joint Committee. 2002. Joint Committee on Taxation, Background Information Relating to the Investment of Retirement Plan Assets in Employer Stock, (JCX-1-02), February 11.

Kandarian, Steven. 2002. "Statement" on the Pension Benefit Guaranty Corporation,before the Committee on Finance, United States Senate, February 27. http://www.pbgc.gov/news/speechs/test_02_27_2002.htm 
Krasner, Jeffrey. 2002. "Polaroid workers dealt new setback on stocks." The Boston Globe, January 20. http://www.boston.com/dailyglobe2/020/nation/Polaroid_workers_dealt_new_setback_on_stocks. $\underline{\mathrm{html}}$

Kruse, Douglas. 2002. "Research Evidence on Prevalence and Effects of Employee Ownership." Testimony for the Subcommittee on Employer-Employee Relations, Committee on Education and the Workforce, US House of Representatives, February 13.

Kruse, Douglas and Joseph Blasi. 1997. "Employee Ownership, Employee Attitudes, and Firm Performance: A Review of the Evidence." In Human Resources Management Handbook. Part 1. Eds. D. Lewin, D.J.B. Mitchell, and M. Zaidi. Greenwich, CT: JAI Press.

Lachance, Marie-Eve and Olivia S. Mitchell. This volume. "Understanding Pension Guarantees".

Lambert, Richard, David Larcker, and Roe Verrecchia. 1991. "Portfolio Considerations in Valuing Executive Compensation." Journal of Accounting Research, 29(1) : 129-149.

Lebow, David, Louise Sheiner, Larry Slifman, and Martha Starr-McCluer. 1999. "Recent Trends in Compensation Practices." Washington DC: Board of Governors of the Federal Reserve System, Working Paper, July.

Leonard, Jonathan S. 1990. "Executive Pay and Firm Performance.” Industrial and Labor Relations Review 43, 3 (February): 13-29.

Leonhardt, David. 2002. "Stock Options Said Not To Be As Widespread as Backers Say." New York Times, July 18: C1. Citing data on stock options from National Center for Employee Ownership, www.nceo.org.22

Mercer (2001). William M. Mercer, Survey on Employee Savings Plans: 2000-2001, New York, New York.

Meulbroek, Lisa. 2000 (a). "The Efficiency of Equity-Linked Compensation: Understanding the Full Cost of Awarding Executive Stock Options.” Harvard Business School Working Paper.

Meulbroek, Lisa. 2002 (b). “Company Stock in Pension Plans: How Costly Is It?” Harvard Business School Working Paper 02-0258.

Moore, James and Olivia S. Mitchell. "Projected Retirement Wealth and Saving Adequacy". In Forecasting Retirement Needs and Retirement Wealth. Eds. O.S. Mitchell, B. Hammond, and A. Rappaport. Pension Research Council. Philadelphia, PA: University of Pennsylvania Press, 2000: 68-94.

Murphy, Kevin J. 2000. "Executive Compensation.” Handbook of Labor Economics 3, Orley Ashenfelter and David Card, eds. Amsterdam, New York and Oxford: Elsevier Science, NorthHolland: 2485-2563.

NCEO. 2002. "A Comprehensive Overview of Employee Ownership.” downloaded 1/22/02. http://www.nceo.org

Olsen, Erik. 2002. "Testimony Before the Senate Committee on Governmental Affairs on Retirement Security: 401K Cris is at Enron.” February 5, 2002. www.senate.gov/ gov_affairs/020502olsen.htm

Office of Management and Budget (OMB). 2002. Budget of the US Government. Chapter 6, Tax Expenditures. www.whitehouse.gov/omb/budget/fy2003/index.html

Oyer, P. and S. Schaefer. 2002. "Why Do Some Firms Give Stock Options to All Employees?” GSB Stanford University working paper. January.

Paton, James. 2002. "Kmart Dive Shows Employee Risk.” Reuters. January 27, 2002. http://news.lycos.com/news/story.asp?section=Business\&storyID=324020 
Peale, Cliff. 2002. "Enron Debacle Spurs P\&G to Examine ESOP: Company Considers more

Diversification." The Cincinnati Enquirer, Friday, January 18, 2002. http://enquirer.com/editions/2002/01/18/fin_enron_debacle_spurs.html

Pensions \& Investments. 2002. "The Top 200 Pension Funds/Sponsors", January 21: 12.

Perun, Pamela. 2000. "Employee Stock Ownership Plans: A Status Report". The Retirement Project Brief, Urban Institute. Washington, DC: June 2000.

Plan Sponsor. 2002. "Insights on Company Stock." Web page on Enron and related company stock controversies. http://www.plansponsor.com/eprise/main/PlanSponsor/News/Finance/costockindex

Purcell, Patrick J. 2002. "Employer Stock in Retirement Plans: Investment Risk and Retirement Security.” Congressional Research Service, Washington, DC. June.

Rosen, Corey. 2002. "New Data Show that ESOPS and 401k Plans Heavily Invested in Company Stock Are More Likely to Have Other Retirement Plans As Well.” 2/17/02 www.nceo.org/columns/cr107.html.

Schneyer, Fred. 2002. “Kmart: Our 401K Plan is Still Safe.” Plansponsor.com. January 24. http://www.plansponsor.com/content/news/finance/kmartbankrupt

Schulz, Ellen E. and Theo Francis. 2002 (a). "Enron Pensions Had More Room at the Top." Wall Street Journal, January 232002, p. A4.

Schulz, Ellen E. and Theo Francis. 2002 (b). “Companies’ Hot Tax Break: 401(k)s.” Wall Street Journal, January 31, 2002, p. C1.

Smiley, Robert W. and Gregory K. Brown. 2001. "Employee Stock Ownership Plans." Handbook of Employee Benefits. Ed. J. Rosenbloom. New York: McGraw Hill.

US Department of Labor. 2002. Data provided to authors on special request.

VanDerhei, Jack. 2002. "The Role of Company Stock in 401(k) Plans - Written Statement for the House Education and Workforce Committee." Employee Benefits Research Institute, Washington, DC. February 13, 2002.

Vanguard Group. 2001. "Expecting Lower Returns in the Short Run.” Vanguard Participant Monitor. Vanguard Center for Retirement Research. November.

Ward, Judy. 2001. “The Match Game.” Plan Sponsor, November: 104, 106. 


\section{Table 1. Aspects of US Private Sector Pension Plans: 1985-2001}

\section{A. Number of Pension Plans}

\begin{tabular}{|c|c|c|c|c|}
\hline Year & Total & $\underline{\text { DB Plans }}$ & $\underline{\text { DC Plans }}$ & $\underline{401(k) O n l y}$ \\
\hline 1985 & 632,135 & 170,172 & 461,963 & 29,869 \\
\hline 1990 & 712,308 & 113,062 & 599,245 & 97,614 \\
\hline 1995 & 693,404 & 69,492 & 623,912 & 200,813 \\
\hline 1998 & 730,031 & 56,405 & 673,626 & 300,593 \\
\hline $2001^{\mathrm{e}}$ & 758,000 & 51,000 & 707,000 & 361,000 \\
\hline
\end{tabular}

B. Number of Active Pension Plan Participants (000)

\begin{tabular}{|c|c|c|c|c|}
\hline Year & Total & $\underline{\text { DB }}$ & $\underline{\mathrm{DC}}$ & $\underline{401(k) O n l y}$ \\
\hline 1985 & 62,268 & 29,024 & 33,244 & 10,339 \\
\hline 1990 & 61,831 & 26,344 & 35,488 & 19,548 \\
\hline 1995 & 66,193 & 23,531 & 42,662 & 28,061 \\
\hline 1998 & 73,328 & 22,994 & 50,335 & 37,114 \\
\hline $2001^{\mathrm{e}}$ & 78,000 & 22,500 & 55,500 & $43,800 *$ \\
\hline
\end{tabular}

C. Pension Plan Assets (\$ millions)

\begin{tabular}{|c|c|c|c|c|}
\hline Year & Total & $\underline{\text { DB }}$ & $\underline{\mathrm{DC}}$ & 401(k) Only \\
\hline 1985 & $\$ 1,252,739$ & $\$ 826,117$ & $\$ 426,622$ & $\$ 143,939$ \\
\hline 1990 & $\$ 1,674,139$ & $\$ 961,904$ & $\$ 712,236$ & $\$ 384,854$ \\
\hline 1995 & $\$ 2,723,735$ & $\$ 1,402,079$ & $\$ 1,321,657$ & $\$ 863,918$ \\
\hline 1998 & $\$ 4,021,849$ & $\$ 1,936,600$ & $\$ 2,085,250$ & $\$ 1,540,975$ \\
\hline $2001^{\mathrm{e}}$ & $\$ 4,000,000$ & $\$ 1,900,000$ & $\$ 2,100,000$ & $\$ 1,700,000$ \\
\hline
\end{tabular}

Note:

A portion of participants may be covered by one or more DB or DC plans.

* 43.8 million estimate for 401(k) plans in 2001 is for active participants. Eligible 401(k) participants are estimated at 58.4 million based on $75 \%$ participation rate.

Source: Data from 1985 to 1998: Form 5500 Reports provided by PWBA-USDOL: Tables E1, E23, E8, E11. ${ }^{\text {e: }}$ Authors' estimates based on US DOL and Federal Reserve Board data. 
Table 2. Recent Performance of Company Stock in Corporate 401(k) Pension Plans

\begin{tabular}{lcl}
\hline Company & $\begin{array}{c}\text { \% of DC plan } \\
\text { in Company Stock }\end{array}$ & $\begin{array}{l}\text { \% Stock Price } \\
\text { Change 3/00-12/01 }\end{array}$ \\
\hline Polaroid & $19 \%$ & $-99.6 \%$ \\
Enron & 41 & -99.6 \\
Global Crossing & 16 & -97.5 \\
Weirton & 16 & -96.4 \\
Crown Cork \& Seal & 11 & -92.5 \\
Providian Financial & 19 & -91.8 \\
KS City Southern & 80 & -91.8 \\
Lucent Technologies & 16 & -89.2 \\
Owens Corning & 25 & -88.5 \\
Montana Power & 25 & -88.0 \\
Northern Telcom & 30 & -86.6 \\
Corning & 32 & -86.0 \\
W.R. Grace & 11 & -84.3 \\
Chiquita Brands & 11 & -82.8 \\
ADC Telcom & 46 & -80.4 \\
\hline
\end{tabular}

Source: Authors' derivations from Farrell (2002).

Table 3. Company Stock and Tax Savings From Large Hybrid 401(k) and ESOP Plans (KSOPs)

\begin{tabular}{lcc}
\hline Company & $\begin{array}{c}\text { \% of DC Plan } \\
\text { in Company Stock }\end{array}$ & $\begin{array}{c}\text { Estimated ESOP Deduction } \\
\text { from EGTRRA }\end{array}$ \\
\hline Abbott Laboratories & 82 & $\$ 28$ \\
Anheuser-Busch & 83 & $\$ 15$ \\
Bank of America & 43 & $\$ 8$ \\
Ford Motor & 50 & $\$ 90$ \\
Marsh \& McLennan & 61 & $\$ 10$ \\
McDonalds & 74 & $\$ 4$ \\
Pfizer & 82 & $\$ 23$ \\
Procter \& Gamble & 92 & $\$ 127$ \\
SBC & 38 & $\$ 56$ \\
Verizon & 51 & $\$ 31$ \\
\end{tabular}

Source: Authors' derivations from Schultz and Francis (2002b). 
Table 4. Company Stock Holdings within DC Plans Over Time

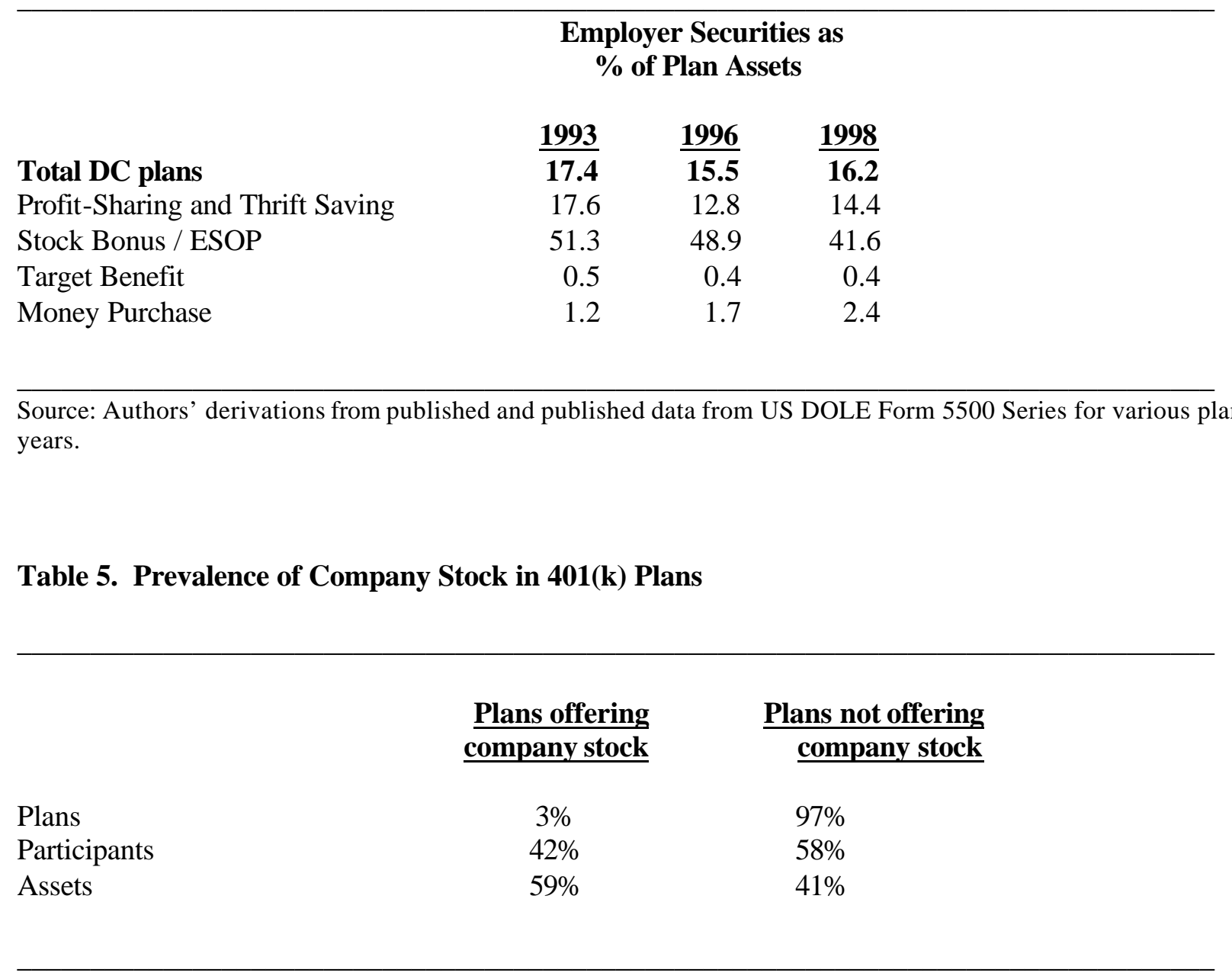

Source: Authors' estimates based on VanDerhei (2002). 
Table 6. Participants With Concentrated Holdings in Company Stock

\begin{tabular}{|c|c|}
\hline$\frac{\text { Asset allocation to }}{\text { company stock }}$ & $\frac{\text { Millions of }}{\text { participants }}$ \\
\hline $0 \%$ & 8.0 \\
\hline $1 \%$ to $20 \%$ & 4.4 \\
\hline $21 \%$ to $40 \%$ & 3.0 \\
\hline $41 \%$ to $60 \%$ & 2.3 \\
\hline $61 \%$ to $80 \%$ & 1.4 \\
\hline Over $80 \%$ & 3.9 \\
\hline TOTAL & 23.0 \\
\hline
\end{tabular}

Total over 20\%:10.6 million participants

Total over 60\%:5.3 million participants

Source: Authors' estimates based on Holden and VanDerhei (2001b) and VanDerhei (2002). 
Table 7. 401(k) Plan Asset Allocation Patterns by Degree of Direction (percent)

\begin{tabular}{|c|c|c|c|c|c|c|}
\hline Type (\% of total plans) & $\begin{array}{l}\text { Equity } \\
\text { funds }\end{array}$ & $\frac{\text { Company }}{\underline{\text { stock }}}$ & $\frac{\text { Balanced }}{\underline{\text { funds }}}$ & $\underline{\text { Bond }}$ funds & $\begin{array}{l}\frac{\text { Money }}{\text { mkt/GIC }} \\
\underline{\text { funds }}\end{array}$ & Other \\
\hline All 401(k) plans & 51 & 19 & 8 & 5 & 14 & 3 \\
\hline All plans w/ company stock (\%) & 44 & 29 & 6 & 4 & 15 & 2 \\
\hline $\begin{array}{l}\text { All plans w/ company stock } \\
\text { and full participant direction (\%) }\end{array}$ & 46 & 22 & 10 & 3 & 17 & 2 \\
\hline $\begin{array}{l}\text { All plans w/ company stock where } \\
\text { employer directs match }(\%)\end{array}$ & 26 & $53 *$ & 5 & 1 & 13 & 2 \\
\hline
\end{tabular}

Note: Includes $33 \%$ of employee monies and $20 \%$ of employer monies

Source: Holden and VanDerhei (2001b) and VanDerhei (2002). 
Table 8. Survey Results on Qualified Plan Restrictions

\section{A. Overall Stock Direction}

Plans that direct contributions into stock: $\quad 45 \%$

Plans that do not direct contributions $\quad 55 \%$

B. Directed Plans: Restrictions Imposed by DC Plans with Contributions Directed to Company Stock

\begin{tabular}{|c|c|c|c|}
\hline \multirow[b]{2}{*}{ Restriction } & \multicolumn{3}{|c|}{$\%$ of plans imposing } \\
\hline & Hewitt 2001 & Mercer 2001 & Vanguard 2001 \\
\hline$\overline{\text { Age }}$ & 34 & 40 & 37 \\
\hline Age/service, including ESOP & 22 & 15 & \\
\hline Restricted until termination & 19 & 12 & 21 \\
\hline Holding period & 3 & 6 & 9 \\
\hline Vesting / Other & 3 & - & 1 \\
\hline Subtotal & $\overline{81} \%$ & $\overline{73 \%}$ & $\overline{68} \%$ \\
\hline No restrictions & 15 & 19 & 13 \\
\hline Caps/maximums & - & - & 5 \\
\hline Other & 4 & $\underline{8}$ & $\underline{14}$ \\
\hline Subtotal & $\overline{19}$ & $\overline{27}$ & 32 \\
\hline Total & 100 & 100 & 100 \\
\hline
\end{tabular}

C. Discretionary Plans: Restrictions Imposed by DC Plans with Employer Contributions Not Made in Company Stock

\section{Restriction}

No restriction

Caps/maximums

Subtotal

Age / age service / ESOP

Restricted until termination

Holding period

Vesting / Other

Subtotal

Total
$\%$ of plans imposing

$$
\begin{aligned}
& 48 \\
& \frac{20}{68}
\end{aligned}
$$

Source: Hewitt (2001); Mercer (2001); Vanguard (2001) 
Figure 1. Participant Knowledge About Risk/Return of Company Stock

Source: Vanguard 2002 [a]

Relative Risk (Scale of 1-10)

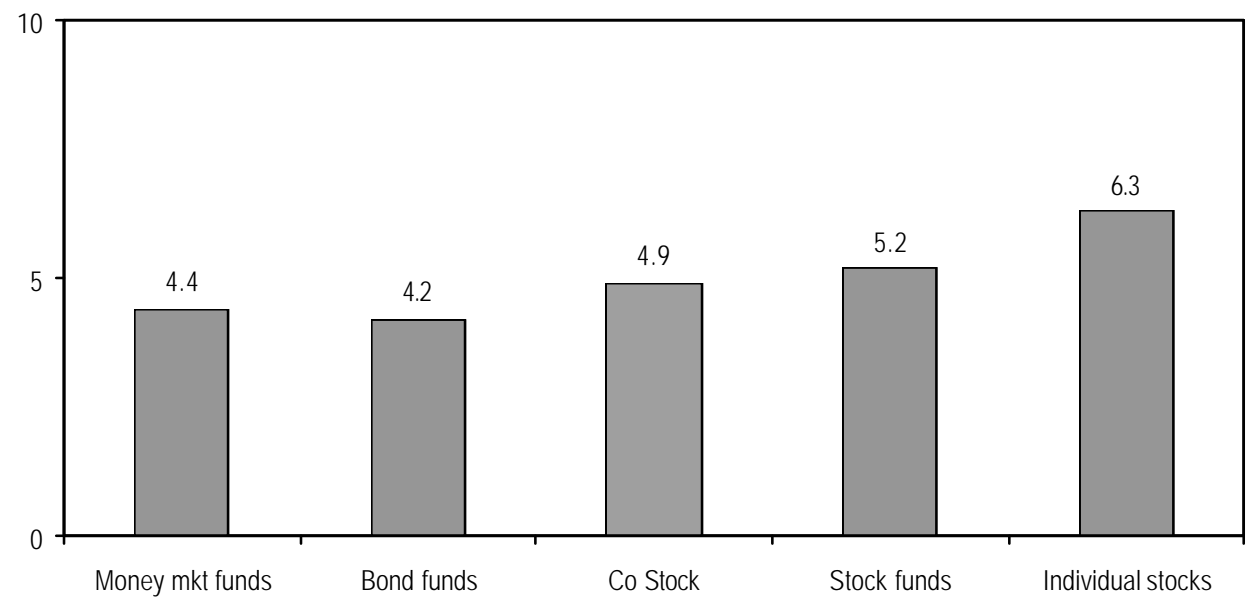


Figure 2. Wealth Outcomes and Company Stock

Source: Authors' computations using Monte Carlo simulations and assumptions below.

A. Assumptions

Initial worker income:

Contribution rate:

Contribution growth rate:

Expected return, market:

Volatility, market:
$\$ 50,000$

$10 \%$

$3 \%$

$10 \%$

$20 \%$
Expected return, company stock: $\quad 10 \%$

Volatility, company stock: $\quad 40 \%$

Correlation, market and company

stock

0.9

\section{B. Wealth Outcomes in 30 Years}

\begin{tabular}{|l|c|c|c|}
\hline & \multicolumn{3}{|c|}{$\begin{array}{c}\text { Expected wealth in } \\
\text { 30 years }\end{array}$} \\
\hline Portfolio mix & $5^{\text {th }}$ Percentile & Median & $\mathbf{9 5}^{\text {th }}$ Percentile \\
\hline $100 \%$ market portfolio & $\$ 281,000$ & $\$ 830,000$ & $\$ 2,733,000$ \\
\hline $\begin{array}{l}50 \% \text { company stock, } \\
50 \% \text { market portfolio }\end{array}$ & $\$ 139,000$ & $\$ 615,000$ & $\$ 3,384,000$ \\
\hline $100 \%$ company stock & $\$ 66,000$ & $\$ 411,000$ & $\$ 4,070,000$ \\
\hline
\end{tabular}

\section{Distribution of Wealth Outcomes in 30 Years}

Retirement Wealth Outcomes After 30 Years

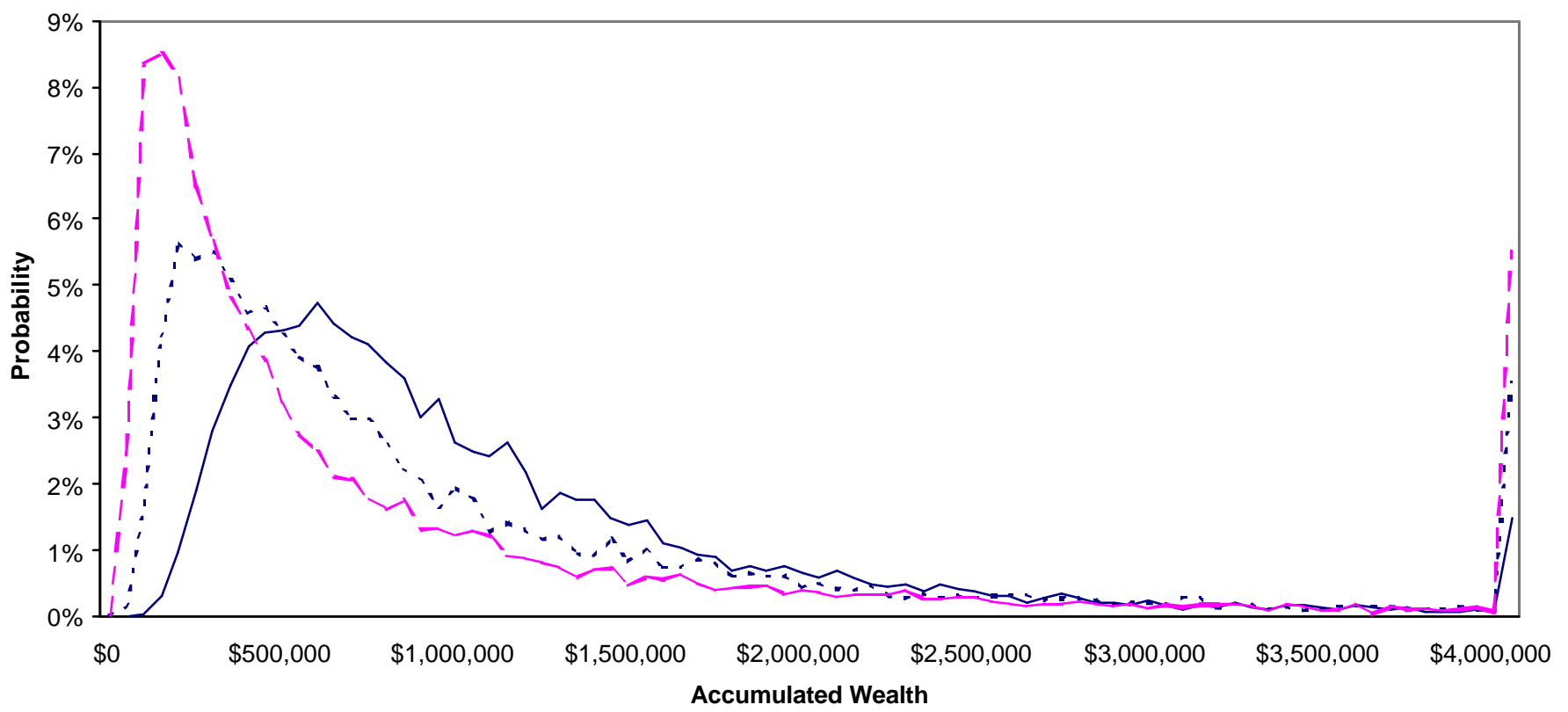

